\title{
Soil moisture control over autumn season methane flux, Arctic Coastal Plain of Alaska
}

\author{
C. S. Sturtevant ${ }^{1}$, W. C. Oechel ${ }^{1}$, D. Zona ${ }^{1,2}$, Y. Kim ${ }^{3}$, and C. E. Emerson ${ }^{1}$ \\ ${ }^{1}$ Global Change Research Group, Department of Biology, San Diego State University, San Diego, California, USA \\ ${ }^{2}$ Research Group of Plant and Vegetation Ecology, University of Antwerp, Wilrijk, Belgium \\ ${ }^{3}$ International Arctic Research Center, University of Alaska Fairbanks, Fairbanks, Alaska, USA
}

Correspondence to: C. S. Sturtevant (sturteva@ sciences.sdsu.edu)

Received: 31 May 2011 - Published in Biogeosciences Discuss.: 8 July 2011

Revised: 15 March 2012 - Accepted: 29 March 2012 - Published: 17 April 2012

\begin{abstract}
Accurate estimates of annual budgets of methane $\left(\mathrm{CH}_{4}\right)$ efflux in arctic regions are severely constrained by the paucity of non-summer measurements. Moreover, the incomplete understanding of the ecosystem-level sensitivity of $\mathrm{CH}_{4}$ emissions to changes in tundra moisture makes prediction of future $\mathrm{CH}_{4}$ release from the Arctic extremely difficult. This study addresses some of these research gaps by presenting an analysis of eddy covariance and chamber measurements of $\mathrm{CH}_{4}$ efflux and supporting environmental variables during the autumn season and associated beginning of soil freeze-up at our large-scale water manipulation site near Barrow, Alaska (the Biocomplexity Experiment). We found that the autumn season $\mathrm{CH}_{4}$ emission is significant (accounting for $21-25 \%$ of the average growing season emission), and that this emission is mostly controlled by the fraction of inundated landscape, atmospheric turbulence, and the decline in unfrozen water during the period of soil freezing. Drainage decreased autumn $\mathrm{CH}_{4}$ emission by a factor of 2.4 compared to our flooded treatment. Flooding slowed the soil freezing process which has implications for extending elevated $\mathrm{CH}_{4}$ emissions longer into the winter season.
\end{abstract}

\section{Introduction}

Methane $\left(\mathrm{CH}_{4}\right)$ is a potent greenhouse gas, exhibiting approximately 25 times the 100 -yr global warming potential of $\mathrm{CO}_{2}$ (Rodhe, 1990; Forster et al., 2007). $\mathrm{CH}_{4}$ emitted from wetlands is the largest single source of atmospheric $\mathrm{CH}_{4}$ world-wide (Denman et al., 2007). Of the estimated $100-231 \mathrm{Tg} \mathrm{CH}_{4} \mathrm{yr}^{-1}$ emitted from wetlands globally (Den- man et al., 2007), arctic wetlands between $60^{\circ} \mathrm{N}$ and $75^{\circ} \mathrm{N}$ are estimated to contribute $23 \mathrm{Tg} \mathrm{CH}_{4} \mathrm{yr}^{-1}$ (Zhuang et al., 2004). However, the rapid changes already occurring in arctic regions such as atmospheric warming, permafrost degradation, and hydrologic change in conjunction with the estimated $1672 \mathrm{Pg}$ carbon stored in northern permafrost soils (Tarnocai et al., 2009) all have the potential to dramatically alter the arctic wetland $\mathrm{CH}_{4}$ contribution (Abelson, 1989; Serreze et al., 2000; Trenberth et al., 2007; Hinzman et al., 2005). There are already signs that the vast arctic soil carbon pool is becoming more available for decomposition and release to the atmosphere (potentially as $\mathrm{CH}_{4}$ ) due to these ecological changes (Oechel et al., 1993; Walter et al., 2006; Schuur et al., 2009). Thus, it is imperative to understand potential changes in $\mathrm{CH}_{4}$ emissions from the Arctic under likely scenarios of climatic change in order to better forecast the global $\mathrm{CH}_{4}$ budget. In this study we approach this research topic from a hydrologic point of view on the Arctic Coastal Plain of Alaska, investigating how experimentally manipulated tundra moistures affect landscape-scale $\mathrm{CH}_{4}$ emissions. We also focus on the autumn season, for which there remains considerable uncertainty in contribution to the annual $\mathrm{CH}_{4}$ budget, both now and under altered tundra moistures.

\subsection{Tundra moisture and $\mathrm{CH}_{4}$ emission}

Moisture, temperature, and labile carbon supply are known to be the major factors influencing $\mathrm{CH}_{4}$ production in wetlands (Christensen et al., 2003), but the sensitivity of $\mathrm{CH}_{4}$ emissions to these factors remains uncertain (Walter and Heimann, 2000). Wetland $\mathrm{CH}_{4}$ emissions are predicted to be highly sensitive to climate change (Roulet et al., 1992; Walter 
and Heimann, 2000), and this may be especially true for arctic regions because in addition to changes in temperature and precipitation, the hydrological regime of arctic ecosystems is likely to be substantially impacted due to permafrost thaw. Increases in active layer thickness and evapotranspiration may lead to better drainage and a general lowering of the water table. On the other hand, ground subsidence connected to the thawing of ice-rich permafrost (thermokarst) may result in more areas of poor drainage and high water retention (Schuur et al., 2008; Smith et al., 2005; Jorgenson et al., 2001). The hydrological trajectory of permafrost regions remains unclear, as changes have currently been observed in both directions, showing increased moisture or increased drying depending on local conditions (Smith et al., 2005; Jorgenson et al., 2006; Plug et al., 2008; Riordan et al., 2006).

A lowered water table typically reduces $\mathrm{CH}_{4}$ emissions due to a higher ratio of aerobic/anaerobic respiration in the soil column and the oxidation of $\mathrm{CH}_{4}$ produced in deeper, anaerobic soil layers as it diffuses through the oxygen-rich surface layer (Whalen and Reeburgh, 1990). However, graminoid vegetation is known to provide a conduit for $\mathrm{CH}_{4}$ through $\mathrm{CH}_{4}$-oxidizing soil layers via roots and stems such that emissions have been highly correlated with vascular species cover and root density (Joabsson and Christensen, 2001; von Fischer et al., 2010). This effect has been specifically noted for Carex aquatilis and Arctophila fulva (Morrissey and Livingston, 1992; Kutzbach et al., 2004), two widespread species in wetlands of the Arctic Coastal Plain of Alaska. Bellisario et al. (1999) found an inverse relationship between water table position and $\mathrm{CH}_{4}$ flux in a Canadian northern peatland, and that greater vascular plant cover was most responsible for higher emissions. Previous water table manipulations have also shown mixed effects of altered water tables on northern wetland $\mathrm{CH}_{4}$ flux. Merbold et al. (2009) experimentally drained a $400 \mathrm{~m}$ diameter region of wetland tundra in the Siberian Arctic which reduced average $\mathrm{CH}_{4}$ flux to less than $4 \%$ of their inundated control plot. However, experimental water table draw-down in a northern peatland near Quebec, Canada showed a general reduction in $\mathrm{CH}_{4}$ emissions but not for low-lying microtopographic sites, and the high spatial variability in emissions from these sites obscured a clear relationship between water table and $\mathrm{CH}_{4}$ flux (Strack and Waddington, 2007). Previous results from our own site in 2007 showed a non-linear effect of water table on $\mathrm{CH}_{4}$ emission (Zona et al., 2009). Increases in inundation depth (height of water above the surface) were found to have a depressive effect on $\mathrm{CH}_{4}$ flux, probably due to increased diffusive resistance, whereas decreases in water table below an already oxic surface layer led to only a minor decrease in flux. Finally, studies of thermokarst lakes in Siberia and Alaska suggest that thermokarst lake formation may significantly increase $\mathrm{CH}_{4}$ emissions via $\mathrm{CH}_{4}$ ebullition from more deeply thawed lake sediments (Walter et al., 2007). Thus, forecasting future $\mathrm{CH}_{4}$ emissions for arctic wetland regions is beset by two key uncertainties: the direction of moisture change and the sensitivity of emissions to this change.

Our study was conducted at the Biocomplexity Experiment ("BE") site near Barrow, Alaska, which was initiated to examine the whole-ecosystem effects of altered tundra moistures on carbon storage and release in this arctic wetland by directly manipulating the water table at the ecosystem level (Zona et al., 2009; Olivas et al., 2010; Lipson et al., 2010; Goswami et al., 2011). This study is unique in that most observational and experimental studies of $\mathrm{CH}_{4}$ flux in arctic tundra have been conducted at the chamberor sub-meter scale, identifying controls at the microtopographic level (e.g. Morrissey and Livingston, 1992; Whalen and Reeburgh, 1992; Christensen, 1993; Christensen et al., 2003; Kutzbach et al., 2004; Mastepanov et al., 2008; von Fischer et al., 2010; Sachs et al., 2010). These studies are extremely important to advance our understanding of the controls and drivers of spatial variability in emission rates. However, chamber-based studies have shown large variation in $\mathrm{CH}_{4}$ emissions over short distances and therefore landscapescale studies using eddy covariance measurements are crucial to integrate the effects of small-scale processes and spatial heterogeneity, but these studies are much fewer in number (Fan et al., 1992; Friborg et al., 2000; Corradi et al., 2005; Wille et al., 2008; Sachs et al., 2008). To date, only one other arctic wetland study has experimentally attributed differences in $\mathrm{CH}_{4}$ flux to landscape-scale hydrologic change, although conducted in a different region (the Siberian Arctic) and using chamber measurements (Merbold et al., 2009). Therefore, our study at the BE provides extremely valuable information on the effects of large-scale changes in tundra moisture conditions on ecosystem-level $\mathrm{CH}_{4}$ fluxes on the Arctic Coastal Plain of Alaska by using both chamber and eddy covariance measurements.

\subsection{Autumn season $\mathrm{CH}_{4}$ emission}

A major shortcoming of most of the studies on $\mathrm{CH}_{4}$ emissions from arctic tundra are the lack of shoulder (spring and autumn) and winter season measurements, due in large part to the difficulty in maintaining measurements during these times. The shoulder seasons represent transitions between high summer emissions and low winter emissions. Most previous investigations study the growing season, basing yearly estimates entirely from this time period (e.g. Sebacher et al., 1986) or extrapolating reduced fluxes throughout the offseason (e.g. Christensen, 1993). Recently, more arctic studies have begun to extend $\mathrm{CH}_{4}$ flux measurements into the autumn (e.g. Merbold et al., 2009; Wille et al., 2008; Mastepanov et al., 2008), but these studies are few and show substantial variation in emissions as well as different rates of change from growing season fluxes. Merbold et al. (2009) showed a sharp decline from large summer emissions as air temperature dropped toward zero, while other studies with more modest summer fluxes have shown gradual autumn 
declines (Sachs et al., 2008; Wille et al., 2008). One study in the Greenland Arctic (Mastepanov et al., 2008) showed very large emissions during the period of soil freezing, suggesting that our current understanding of the seasonality of $\mathrm{CH}_{4}$ flux in arctic regions may need revision. Understanding the rate and timing of the shoulder season transitions across the Circumpolar Arctic is critical to improving annual estimates of $\mathrm{CH}_{4}$ flux for this biome. Also, understanding the sensitivity of these seasonal transitions to altered moisture regimes is important for accurate and sophisticated forecasts of feedbacks between arctic greenhouse gas emissions and global climate change.

In this study we investigated ecosystem-level $\mathrm{CH}_{4}$ flux during the autumn season of 2009 under manipulated soil moisture conditions, representing among the first of these measurements outside the growing season. An opportunity to use pre-production versions of a newly developed open-path $\mathrm{CH}_{4}$ analyser allowed us to conduct autumn eddy covariance measurements, capturing landscape-scale $\mathrm{CH}_{4}$ fluxes during the decline in temperature and onset of soil freezing when most biological activity in this arctic landscape decreases markedly. We also present chamber measurements of $\mathrm{CH}_{4}$ flux during the autumn of 2007 which allowed us to investigate how small-scale variations in inundation status help to explain landscape-scale fluxes. Our goals were to (1) understand the ecosystem-level effect of experimentally raised or lowered water tables on autumn $\mathrm{CH}_{4}$ emissions, (2) quantify the importance of autumn $\mathrm{CH}_{4}$ emissions in relation to typical 100-day growing season estimates, and (3) identify the most important environmental factors controlling the transition between summer and winter $\mathrm{CH}_{4}$ emissions. According to previous research during the growing season at this site (Zona et al., 2009), we expected water table height to be a key controller of $\mathrm{CH}_{4}$ flux, with the largest emissions observed for water tables just above the surface. In addition, we expected that the transition between late summer and early winter $\mathrm{CH}_{4}$ flux would largely be controlled by temperature, as soil temperature was found to be the greatest driver of variation in $\mathrm{CH}_{4}$ emissions during the growing season (Zona et al., 2009). Finally, as microtopographical variation in water table was found to be in important control on the ecosystem respiration from this site (Zona et al., 2011), we expected it to play a significant role in landscape-scale $\mathrm{CH}_{4}$ flux.

\section{Site description}

\subsection{General region}

The BE is located on the North Slope of Alaska near the village of Barrow (Fig. 1 inset). The terrain in this region consists mostly of poorly drained, acidic, wet meadow tundra of minimal relief. This area is underlain by continuous permafrost to depths greater than $300 \mathrm{~m}$ (Brewer, 1958 ) with active layer thickness (maximum depth of sea- sonally thawed ground) ranging from 30 to $90 \mathrm{~cm}$ (Bockheim et al., 1999). Small-scale topography (microtopography) is largely attributed to polygon-patterned ground created by the formation and expansion of long, intersecting ice-wedges which push up soil to either side as they develop (Leffingwell, 1919). The Gelisol soils in this region are reworked, unconsolidated Quaternary marine sediments (Black, 1964) with major taxons of Typic Aquiturbel, Typic Histoturbel, and Typic Aquorthel (Bockheim et al., 1999). Vegetation is dominated by grasses, sedges, and mosses along with a few prostrate dwarf shrubs (Muller et al., 1999; Raynolds et al., 2005). Snow melt typically occurs in the first week of June and freeze-up occurs in late September and October. Mean annual air temperature and precipitation (1971 to 2000) are $-12{ }^{\circ} \mathrm{C}$ and $106 \mathrm{~mm}$, respectively. The climate near Barrow is generally representative of other coastal arctic wetland regions in the North American and Eurasian Arctic in terms of mean annual air temperature, but is generally much lower in precipitation than the Eurasian Arctic. Mean summer temperature (June to August) is $3.3^{\circ} \mathrm{C}( \pm 1.0$ s.d.), and mean autumn temperature (September and October) is $-5.1^{\circ} \mathrm{C}$ ( \pm 2.5 s.d.). The year 2009 was warmer than average; summer and autumn air temperatures were $4.6^{\circ} \mathrm{C}$ and $-1.2^{\circ} \mathrm{C}$, respectively. Most of the precipitation in this region accumulates between June and September (74.1 $\mathrm{mm} \pm 28.8$ s.d.). Precipitation during these months in 2009 was also greater than average $(95 \mathrm{~mm})$.

\subsection{Biocomplexity Experiment site}

$\mathrm{CH}_{4}$ fluxes were recorded at the Biocomplexity Experiment site (Fig. 1). The BE is located within the Barrow Environmental Observatory about $6 \mathrm{~km}$ east of Barrow village and $6.5 \mathrm{~km}$ south of the Arctic Ocean $\left(71^{\circ} 17^{\prime} 2.6^{\prime \prime} \mathrm{N}\right.$, $\left.156^{\circ} 35^{\prime} 45.6^{\prime \prime} \mathrm{W}\right)$. The $\mathrm{BE}$ is centered on a vegetated thaw lake basin estimated to have drained 50 to $300 \mathrm{yr}$ before present (Hinkel et al., 2003).

Thaw lake basins form when one of the numerous and typically shallow lakes in this region drains as a result of several potential mechanisms, such as stream capture or erosion of an outlet channel (Cabot, 1947; Carson, 1968). The lakes originate due to local permafrost thaw and wind-driven expansion (Cabot, 1947; Carson, 1968). After drainage, the basin undergoes a several thousand year evolution of ice wedge polygon growth, changing soil characteristics, vegetation colonization and succession, and perhaps lake reformation or partial capture by another lake during the cycle (Billings and Peterson, 1980; Hinkel et al., 2003; Jorgenson and Shur, 2007). An aerial view of the Barrow Peninsula (and the Arctic Coastal Plain of Alaska in general) reveals a collage-like landscape of lakes and vegetated drained basins that drained at various times in the past $5500 \mathrm{yr}$ (Carson, 1968; Hinkel et al., 2003). Together, thaw lakes and vegetated thaw lake basins account for $66-72 \%$ of the land surface in the Barrow region (Hussey and Michelson, 1966; 


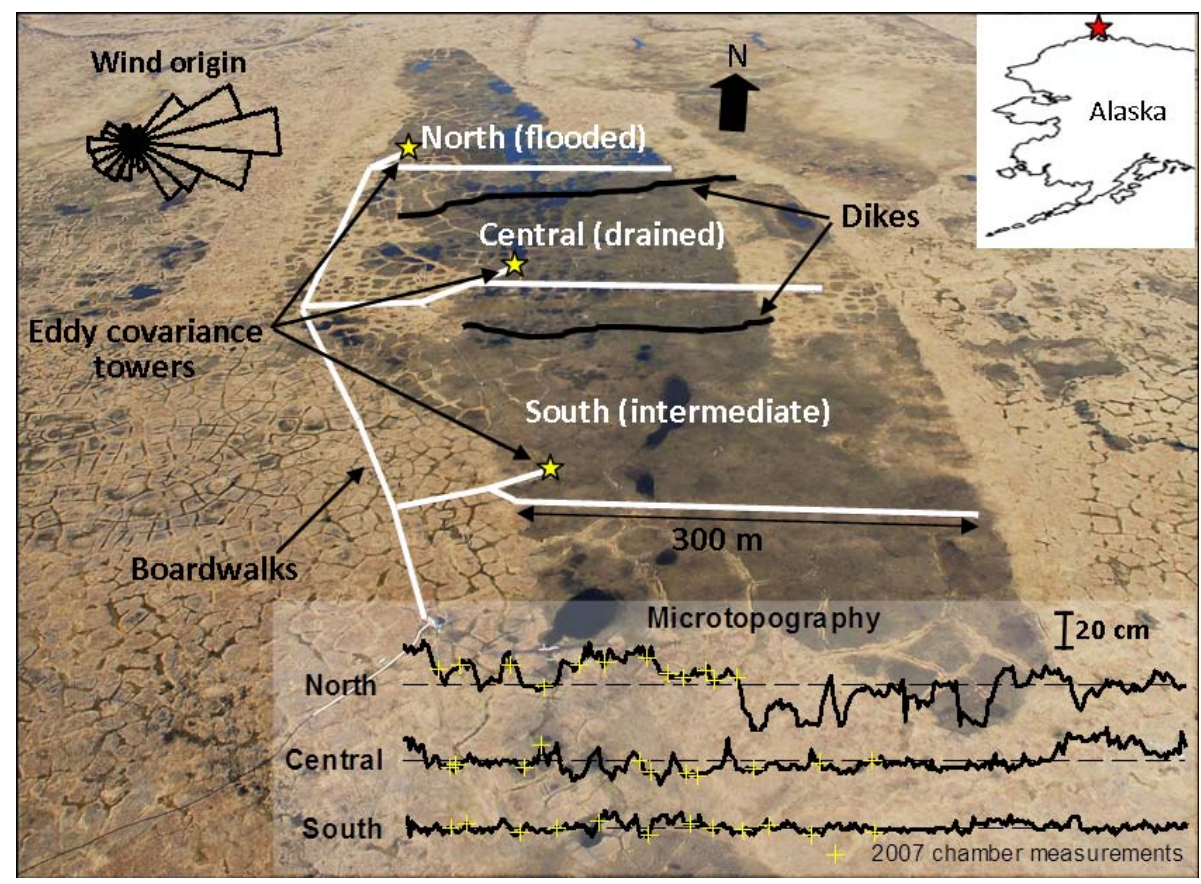

Fig. 1. Oblique aerial view of the Biocomplexity Experiment site. The wind rose in the top left of the image shows the wind direction histogram for the autumn period of 2009 (19 August to 25 October). The lower plots show microtopographical differences along the boardwalks measured by DGPS.

Frohn et al., 2005), making this site generally representative of a large proportion of the Arctic Coastal Plain.

The BE basin (Fig. 1) is approximately $1.4 \mathrm{~km}$ long $\times$ (up to) $0.4 \mathrm{~km}$ wide, oriented in a north-south direction. The basin is of minimal relief, with the lower portions of the basin set less than $1.5 \mathrm{~m}$ below the surrounding tundra. Within the basin there is low to moderate ice wedge polygon development which, along with microtopography (Fig. 1 inset), decreases from north to south. Vegetation is dominated by Sphagnum mosses and wet and moist vascular communities (Carex Aquatilis, Eriophorum scheuchzeri, Dupontia fisherii, Arctophila fulva) (Olivas et al., 2010). Average vegetation height is $15-30 \mathrm{~cm}$ above the nearly continuous moss layer. The organic layer in the Biocomplexity basin is approximately $12-15 \mathrm{~cm}$ thick and is underlain by a silty, marine-derived mineral layer (Lipson et al., 2010). Active layer thickness at this site is comparable to other drained lake basins in the area. In 2009, average active layer thickness for the control/intermediate moisture section of the $\mathrm{BE}$ was $34 \mathrm{~cm}$, which was similar to the 1995-2009 average of Barrow-area drained lake basin tundra $(36 \mathrm{~cm} \pm 10$ s.d.) presented by Shiklomanov et al. (2010).

In the spring of 2007 the BE basin was divided into three sections (North, Central, and South) by dikes. Two sets of dikes were inserted into the permafrost extending from the east to west edges of the basin to restrict the movement of water toward the natural drainage at the southern end (Zona et al., 2009) and to isolate the water tables in each section.
Boardwalks run along the western edge of the basin as well as in three east-west transects to enable frequent sampling in each section without damage to the tundra. An eddy covariance tower is located in the western part of each section, as prevailing winds are from the east.

\section{Materials and methods}

\subsection{Water table manipulation}

The objective of the manipulation was to increase the water table by $15 \mathrm{~cm}$ in the North (flooded) section, decrease the water table by $15 \mathrm{~cm}$ in the Central (drained) section, and use the South section as a control or intermediate water table. Treatment was conducted by pumping water from ponded low-center polygons in the Central (drained) section to the North (flooded) section using high capacity pumps and hoses, beginning immediately after snowmelt and until surface water could no longer be removed (due to water removal as well as the natural drop in water table as thaw depth increased). In 2008 and 2009 additional water was pumped from a nearby pond into the North (flooded) section to maintain the water table in this section. Evaluation of the water chemistry of this pond was similar to standing pond water in the $\mathrm{BE}$ basin with low nutrient content $\left(\mathrm{NH}_{4}^{+}\right.$and $\left.\mathrm{PO}_{4}^{-}\right)$and $\mathrm{pH}$ similar to equilibrium with the atmosphere (D. Lipson, personal communication, 2011). 


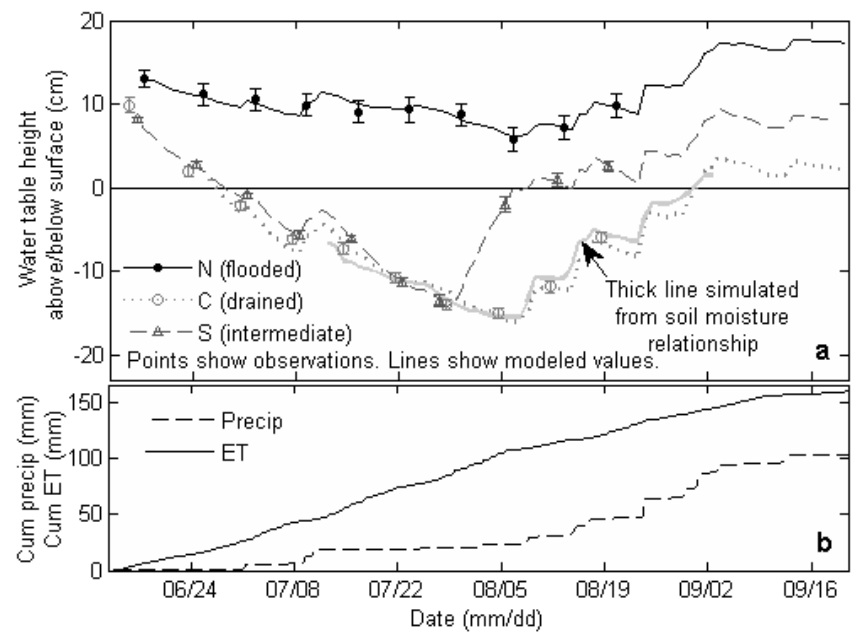

Fig. 2. Water table position (a) measured during the growing season (points) and simulated in the autumn using an empirical model (lines) until the refreezing of the active layer. The additional thickened line for the Central (drained) section shows an independently simulated water table using the relationship between measured water table and soil moisture in the top $10 \mathrm{~cm}$ of soil during the growing season. Error bars show standard error of the mean. The lower panel (b) shows cumulative adjusted precipitation and cumulative potential evapotranspiration from 15 June 2009 (used in the water balance model).

Although treatment activities were maintained in all three years of the manipulation (2007, 2008, and 2009), interannual differences in water availability and climatic conditions caused the treatment effects to differ between years and from target values (see Olivas et al., 2010 for a detailed history of the water table manipulation prior to 2009). In 2008 and 2009 the desired direction of change for all sections was achieved, for the entirety of the 2008 growing season and after late July in 2009. For the early- to mid-2009 growing season, high water tables were maintained in the North (flooded) section but the early-season removal of water from the Central (drained) section did not create a significant difference in water table between the Central and South (intermediate) sections (see Fig. 2a). We do not know the exact reasons for this, as water pumped from the Central (drained) section effectively increased the water table in the North (flooded) section. In late July of 2009 , we decided to add water to the South section and remove it as a "control" in order to differentiate the Central (drained) and South water tables. We felt that it was more scientifically valuable to evaluate the ecosystem at different water tables than to adhere to the concept of a control, since we cannot definitively argue that it remained unaffected by the manipulation. Water table differences among all three sections were achieved after 29 July.

\subsection{Eddy covariance instrumentation}

Fluxes of $\mathrm{CH}_{4}, \mathrm{CO}_{2}$, and $\mathrm{H}_{2} \mathrm{O}$ were measured at a height of $1.9 \mathrm{~m}$ above the moss layer using typical eddy covariance instrumentation with the addition of a newly developed open-path $\mathrm{CH}_{4}$ analyser. Flux data were taken at $10 \mathrm{~Hz}$ and recorded with a datalogger. Three-dimensional wind speed and virtual sonic temperature were collected with a CSAT3 sonic anemometer (Campbell Scientific, Logan, Utah, USA). Molar densities of $\mathrm{CO}_{2}$ and $\mathrm{H}_{2} \mathrm{O}$ were collected with an open-path LI-7500 infrared gas analyser (LICOR Biosciences, Lincoln, NE, USA). $\mathrm{CH}_{4}$ molar density was measured with a pre-production version of the nowcommercial open-path LI-7700 $\mathrm{CH}_{4}$ analyser (LI-COR Biosciences, Lincoln, NE, USA). The pre-production units used in this study were nearly identical to the final production instruments and have shown performance characteristics wellsuited to eddy covariance measurements (McDermitt et al., 2010).

The LI-7500 and LI-7700 gas analysers were calibrated before and after the study period via a 2-point linear equation. Ultra high purity nitrogen was used as the zero for $\mathrm{CH}_{4}$, $\mathrm{CO}_{2}$, and $\mathrm{H}_{2} \mathrm{O}$. High precision gases with certification accuracy $<1 \%$ were used as span values for $\mathrm{CH}_{4}(4 \mathrm{ppm}$ in a balance of VOC-free air) and $\mathrm{CO}_{2}(750 \mathrm{ppm}$ in a balance of nitrogen). The span value for $\mathrm{H}_{2} \mathrm{O}$ was generated with a LI610 dew point generator (LI-COR Biosciences, Lincoln, NE, USA) using a dew point $5^{\circ} \mathrm{C}$ below ambient air temperature.

The $\mathrm{CH}_{4}$ analysers were installed at the BE on $19 \mathrm{Au}-$ gust 2009. We intended to have the use of three of the prototype LI-7700 sensors to collect $\mathrm{CH}_{4}$ flux measurements in each of the three manipulation sections during the autumn. However, instrument damage resulted in the immediate loss of the Central (drained) section prototype, leaving sensors at only the North (flooded) and South (intermediate) sections. Shortly before we received a replacement instrument for the Central section on 9 September, the prototype LI-7700 in the South section was damaged as well. Unfortunately, there was not another replacement for the South section. Since the South (intermediate) site was not a true control and there were only two available instruments, we felt the most worthwhile comparison would be between the wettest (North) and driest (Central) conditions. Therefore, the periods of $\mathrm{CH}_{4}$ flux measurement for each manipulation section were as follows: North (flooded) section from 19 August to 25 October, South (intermediate) section from 19 August to 7 September, and Central (drained) section from 9 September to 25 October. For clarity in presentation, most environmental data from each section will only be reported for the concurrent $\mathrm{CH}_{4}$ flux measurement periods.

\subsection{Eddy covariance $\mathrm{CH}_{4}$ flux computations}

Half-hourly flux calculations of $\mathrm{CH}_{4}$, carbon dioxide, water vapour, energy, and momentum were made using the 
eddy covariance method (Baldocchi et al., 1988) and coded in MATLAB v. 7.12.0 (Mathworks, Natick, Massachusetts, USA). Prior to covariance computations for each half hour, the sonic anemometer coordinate frame was double-rotated to align with the mean streamline and signals from separate sensors were time-aligned by maximizing the crosscorrelation between vertical wind speed and scalar concentration. Appropriate corrections were applied for the simultaneous vertical transfer of heat and water vapour (Webb et al., 1980; McDermitt et al., 2010) as well as for high frequency spectral loss due to sensor separation and path length averaging (Moore, 1986). A footprint model (Hsieh et al., 2000) was used to determine the typical upwind distance contributing to the flux, and identified that under typical conditions $80 \%$ of measured fluxes could be attributed to the first $135 \mathrm{~m}$ of tundra upwind from the tower.

Quality control was applied pre- and post- flux computation (see Supplement A for a breakdown). Raw $10 \mathrm{~Hz}$ data were de-spiked ( $>6$ standard deviations from the running mean) and removed of periods clearly demonstrating error due to heavy fog, mist, rain, or snow. Computed fluxes were filtered according to stationarity and integral turbulence characteristics tests following Foken at al. (2004). Fluxes calculated under low turbulence conditions (friction velocity $<0.1 \mathrm{~m} \mathrm{~s}^{-1}$ ) or when winds originated from outside the manipulation footprint were excluded.

Finally, the overall integrity of the fluxes passing automatic quality control was assessed by the flux cospectra and energy budget closure. Evaluation of the flux cospectra showed good agreement with the empirical curves of Kaimal et al. (1972). Energy budget closure included terms for sensible and latent heat fluxes, net radiation, and soil heat flux, and averaged $84 \%$ prior to the onset of soil freezing, which is better than the average closure reported for eddy covariance studies (79\%; Wilson et al., 2002). After soil freezing began, energy closure averaged $159 \%$; however, this is consistent with additional energy release during the phase change from liquid water to ice within the soil column (Tanaka et al., 2003; Guo et al., 2011) in relation to low net radiation values.

After quality checks and exclusion of fluxes originating outside the manipulation area, a total of 1481 half-hourly flux measurements (all three sections combined) were retained for analysis (see Supplement A). On average, this represented $25 \%$ of the time a $\mathrm{CH}_{4}$ analyser was stationed in each manipulation section, which is not surprising given the adverse weather conditions and shifting winds (see Fig. 1 inset) experienced at this site during the study period. No substantial difference existed between the proportions of retained daytime and night-time measurements, nor did the number of retained measurements differ greatly between sections during the concurrent measurement periods.

\subsection{Chamber-based $\mathrm{CH}_{4}$ flux}

We also present chamber-based $\mathrm{CH}_{4}$ flux measurements taken in the autumn of 2007 from 13-18 September. Although these measurements were taken during a different year and with a different manipulation effect than our 2009 eddy covariance measurements, the small-scale spatial relationships we observed between soil moisture and $\mathrm{CH}_{4}$ flux in our 2007 chamber measurements help to explain our ecosystem scale results of 2009. The flux chamber $(65 \mathrm{~cm}$ diameter; $50 \mathrm{~cm}$ high) was deployed on the soil surface at each of 12 locations along the western $200 \mathrm{~m}$ of the boardwalk in each manipulation section (see Fig. 1 inset). The chamber was equipped with fixed clear plastic tubing ( $1 \mathrm{~mm}$ ID and $3 \mathrm{~mm} \mathrm{OD;} 100 \mathrm{~cm}$ long) for the air sampling and a fan for mixing of air sample. Four air samples were drawn from the headspace in the chamber at approximately 10-min intervals after chamber deployment. The $10 \mathrm{ml}$ samples were collected using a $50 \mathrm{ml}$ plastic syringe at a rate of $5 \mathrm{ml}$ per minute to a $10 \mathrm{ml}$ vial. The vials were transferred to the laboratory for the analyses of $\mathrm{CO}_{2}$ and $\mathrm{CH}_{4}$ concentrations with a gas chromatograph equipped with a thermal conductivity detector (TCD-GC, GC-14B Shimadzu Ltd., Japan), a column packed Porapack Q (80/100 mesh) and a flame ionization detector (FID-GC, GC-14B Shimadzu Ltd., Japan) with molecular sieve $13 \times(80 / 100$ mesh), respectively. Calibrations of $\mathrm{CO}_{2}$ and $\mathrm{CH}_{4}$ were done with a series of standard gases containing $338 \pm 7,491 \pm 10$ and $5000 \pm 100 \mathrm{ppmv}$ of $\mathrm{CO}_{2}$ in synthetic air (Scott Gas Co., USA) and $0.79 \pm 0.016$, $1.61 \pm 0.02$ and $2.43 \pm 0.048$ ppmv of $\mathrm{CH}_{4}$ in synthetic air (Scott Gas Co., USA), respectively. Precisions with the calibration ranges were usually better than $2 \%$. The flux was calculated from the gradient of the relationship between gas concentration and sampling time with a correlation coefficient above 0.99 and linear curve (Kim and Tanaka, 2003; Kim et al., 2007). During the flux-measurement, volumetric soil moisture in the top $6 \mathrm{~cm}$ of soil was measured with a portable soil-moisture logger (HH2, Delta-T Devices, UK) with sensor (ML2, Delta-T Devices, UK).

\subsection{Environmental measurements}

Eddy covariance measurements were accompanied by a suite of environmental measurements, which are recorded yearround in the vicinity of each tower and within the manipulation footprint. Air temperature and relative humidity were measured at $1.6 \mathrm{~m}$ height with a HMP45C probe with radiation shield (Vaisala, Helsinki, Finland). Atmospheric pressure was measured at the Central tower with a PTB 101B electronic barometer (Vaisala, Helsinki, Finland). Temperatures at the soil surface (within the moss layer), $1 \mathrm{~cm}, 5 \mathrm{~cm}$, $10 \mathrm{~cm}, 20 \mathrm{~cm}$, and $30 \mathrm{~cm}$ depths were measured with type $\mathrm{T}$ thermocouples. The standard calibration instruction for the type $\mathrm{T}$ thermocouple was applied in the CR23X datalogger. During the autumn of 2009 we experienced a loss 
of the thermocouple at $10 \mathrm{~cm}$ depth in the North section and those below $5 \mathrm{~cm}$ in the South section; therefore we are missing data at these locations and depths. Soil moistures were recorded at three depth increments $(0-30 \mathrm{~cm}, 0-10 \mathrm{~cm}$, and 20-30 cm) with $30 \mathrm{~cm}$-long CS616 time domain reflectometry probes (Campbell Scientific, Logan, Utah, USA). The 0$30 \mathrm{~cm}$ depth soil moisture probes were inserted vertically into the soil while the probes for the other two depth ranges were inserted diagonally to integrate soil moisture over the measured depth. Uncalibrated volumetric water contents were converted to \% saturation by unfrozen moisture (\% of available pore space occupied by unfrozen water) by applying a linear scaling equation which forces a maximum value to $100 \%$ and forces a minimum value to $8-14 \%$ saturation during winter, depending on depth. Maximum values were obtained from data at the site when the water table was known to be above the sensor level and thaw depth below the sensor level, and minimum values were obtained during winter at the coldest soil temperatures. Data from Hinzman et al. (1991) (soil porosity and minimum unfrozen volumetric moisture content during winter) were used to calculate the minimum \% saturation for the organic and mineral layers. A $1.5 \mathrm{~m}$ tripod housed radiation instruments measuring: upwelling and downwelling photosynthetically-active radiation (PAR, 400-700 nm) with LI-190 quantum sensors (LI-COR Biosciences, Lincoln, NE, USA), and net radiation (0.25$60 \mu \mathrm{m})$ with a Q7 net radiometer (REBS, Bellvue, Washington, USA). Ground heat flux at $2 \mathrm{~cm}$ depth was averaged over five HFT3 ground heat flux plates (REBS, Bellvue, Washington, USA). Finally, a TR-525M tipping rain gauge bucket measured liquid precipitation (Texas Electronics, Dallas, Texas, USA). These environmental variables were measured at $1 \mathrm{~Hz}$ and averaged into half-hour blocks.

During the growing season (prior to the autumn measurement period), thaw depth and water table position were recorded each week every $4 \mathrm{~m}$ along the entire length of the east-west boardwalks traversing each section. Thaw depth was measured by inserting a pointed, graduated metal rod into the ground until reaching frozen soil. Water table position was measured relative to the surface (top of the green moss layer) using $2.5 \mathrm{~cm}$ perforated PVC tubes installed in the permafrost. Measurements of thaw depth and water table position were not continued past 19 August (the start of the autumn measurement period) as support personnel were reduced to a minimum at the end of the growing season. However, approximate values of these two variables were reconstructed for the autumn period using relationships with other measurements derived during the growing season.

Supplement B gives a detailed description of the methods used to reconstruct water table and soil thawing/freezing dynamics. To summarize, we developed an empirical 1dimensional water balance equation fit with data from the growing season and propagated it forward into the autumn at a daily time step. Average water table positions (Fig. 2a) were reconstructed from the last field measurements on

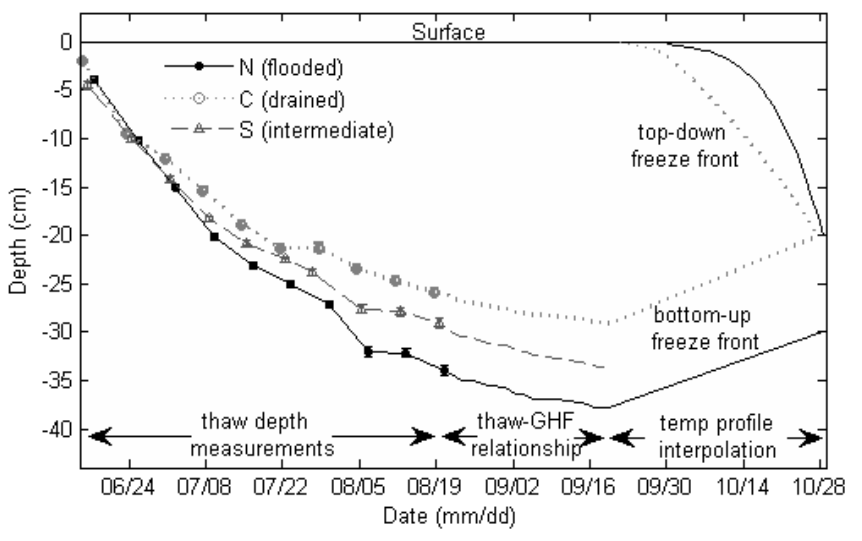

Fig. 3. Thawing and freezing fronts measured during the growing season and simulated for the autumn. Points indicate thaw depth measurements and lines show simulated thawing and freezing fronts. From 19 August to 19 September, the thawing front was simulated with ground heat flux measurements. After 19 September, the thawing and freezing fronts were reconstructed by interpolating between the dates when the temperature at a specific soil depth decreased consistently below $0^{\circ} \mathrm{C}$. Error bars show standard error of the mean.

19 August until 21 September after top-down soil freezing began. It is reasonable to assume that water tables in the manipulation sections did not change substantially after 21 September because of the low amounts of liquid precipitation and evapotranspiration after this date. Prior to refreezing of the active layer (before 19 September), average thaw depths (Fig. 3) were reconstructed using the relationship between thaw depth and cumulative ground heat flux (see Fig. B1 in Supplement B). From 19 September to 28 October, soil freezing fronts (Fig. 3) in the North (flooded) and Central (drained) sections were reconstructed by interpolating soil temperature profiles (Fig. $4 \mathrm{a}$ and b). We did not reconstruct South (intermediate) freezing fronts due to the absence of flux data after 7 September.

\subsection{Statistical analysis}

Data were statistically analysed using the MATLAB v. 7.12.0 Statistics Toolbox on the daily averaged eddy covariance flux data $(N=33$ for North (flooded); $N=23$ for Central (drained); $N=10$ for South (intermediate)) and individual chamber measurements $(N=36)$. The minimal diurnal pattern observed in eddy covariance fluxes of $\mathrm{CH}_{4}$ allowed us to compute daily averages as long as three hours of data were present. We used t-tests to compare $\mathrm{CH}_{4}$ fluxes between manipulation sections (paired t-test by date) or chamber measurements grouped by other factors (2-sample t-tests, unequal variances). Correlation analyses were used to identify environmental variables contributing to the variation in $\mathrm{CH}_{4}$ flux in each manipulation section. One measurement of particularly low $\mathrm{CH}_{4}$ flux measured by eddy covariance in 


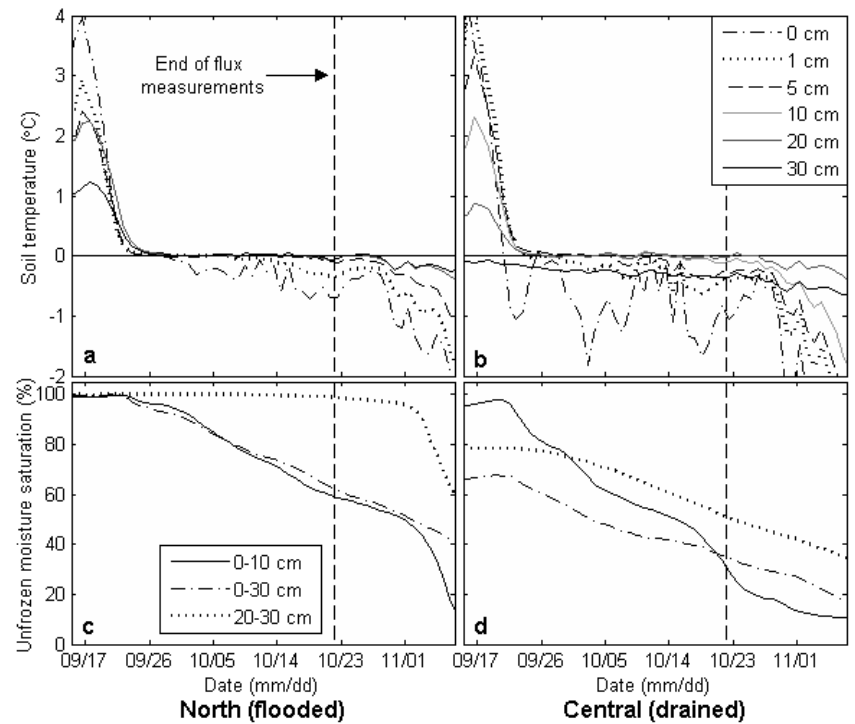

Fig. 4. Soil temperature profiles (a and $\mathbf{b})$ and unfrozen moisture saturations (c and d) in the North (flooded; left column) and Central (drained; right column) sections during the period of soil freeze. Note that the soil temperature sensor at $10 \mathrm{~cm}$ depth in the North section was non-functional during this time. The vertical dotted line indicates the date of last non-rejected flux measurements.

the Central (drained) section was excluded from the correlation analysis because it served as an outlier with strong influence that obscured meaningful relationships. Stepwise multiple linear regression was used to identify the fewest and most ecologically relevant combination of environmental variables explaining the variation in ecosystem-level $\mathrm{CH}_{4}$ flux. An alpha level of 0.05 was used for all statistical procedures.

\section{Results}

\subsection{Environmental conditions during the autumn of 2009}

Mist and fog were common throughout the autumn, present on average about $4 \mathrm{~h}$ of every day according to records at Wiley Post-Will Rogers Memorial Airport (approximately $6.5 \mathrm{~km}$ west of the BE). There was a relatively rainy period in the early autumn; of the $51 \mathrm{~mm}$ liquid precipitation measured at the site during the autumn, $43 \mathrm{~mm}$ fell between 23 August and 3 September (Fig. 5d). Light snow fell intermittently after 19 September and heavy snow began falling on 21 October and lasted to the end of the study period ( 25 October). Long term snow accumulation at Wiley Post began on 16 October and reached $15 \mathrm{~cm}$ by 25 October (Fig. $5 \mathrm{~d}$ ). Air temperature generally fell throughout the study period, dropping consistently below $0{ }^{\circ} \mathrm{C}$ after 19 September and reaching a minimum daily average of $-8^{\circ} \mathrm{C}$ on 21 October (Fig. 5b). Wind speeds varied greatly, ranging from calm conditions to a daily average maximum of $12.7 \mathrm{~m} \mathrm{~s}^{-1}$ (Fig. 5c), and

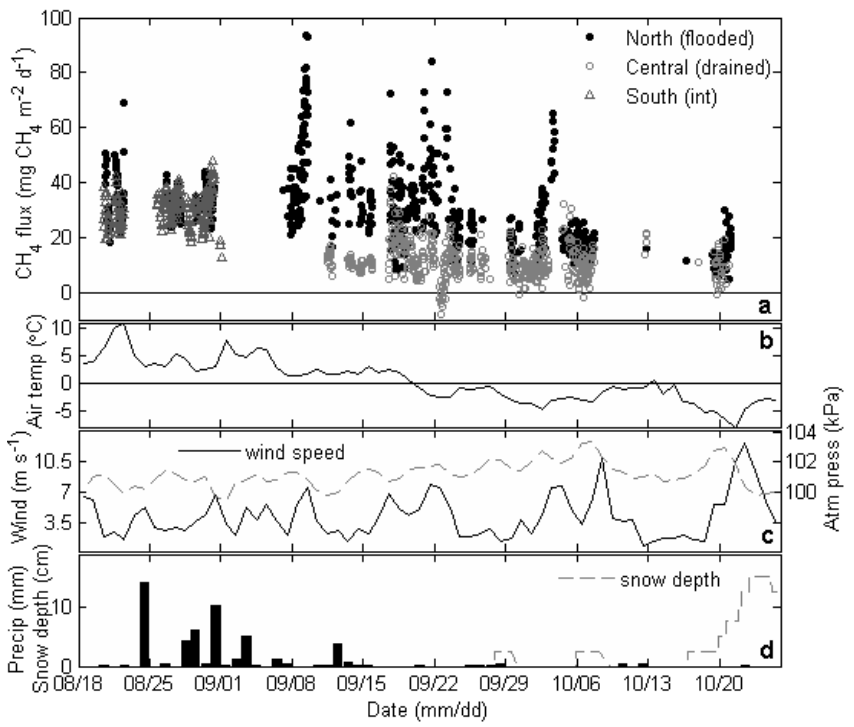

Fig. 5. Half-hourly eddy covariance $\mathrm{CH}_{4}$ flux measurements and selected daily average environmental measurements.

high winds corresponded to relative drops in pressure. Winds were predominantly from the east but ranged from all sectors (Fig. 1 inset).

On 19 August, field measurements showed the average water table was $9.9 \mathrm{~cm}( \pm 12$ s.d. $)$ above the surface in the North (flooded) section, $2.5 \mathrm{~cm}$ ( \pm 5.2 s.d.) above the surface in the South (intermediate) section, and $6 \mathrm{~cm}( \pm 5.2$ s.d.) below the surface in the Central (drained) section (Fig. 2a). All mean differences were highly significant $(p<0.001)$. Results from our empirical model extending the growing season measurements showed that differences among the manipulation sections continued into the autumn, and the water tables in all sections rose substantially due to the late August rainy period. The average water table in each section rose steadily until 3 September at which point it generally levelled off until top-down soil freezing began around 21 September. Our model estimated that the average water table in the North (flooded) section remained $16-18 \mathrm{~cm}$ above the surface, the South (intermediate) section 7-9 $\mathrm{cm}$ above the surface, and the Central (drained) section just above the surface in the range of $1-4 \mathrm{~cm}$.

Although the water table in the North (flooded) section was approximately $8 \mathrm{~cm}$ higher than the South (intermediate) section during the early autumn, the more variable topography in the North section (see Fig. 1 inset) resulted in a similar proportion of inundated surface for both sections (due to polygon rims remaining above surface in the North section and a water table above the surface in the generally flat South section). Using the surface elevations along the boardwalk in each section to calculate the proportion of the surface which would be inundated (below the water table) for the average water table positions during the concurrent NorthSouth measurement period (19 August to 7 September), we 
found that approximately $82 \%$ of the surface was inundated in the North section compared to $86 \%$ in the South section. These calculated proportions agreed with our water table measurements taken every $4 \mathrm{~m}$ along the boardwalk during the growing season when the water tables showed similar values. Later, during the concurrent North-Central measurement period prior to soil freezing (9-21 September), the proportion of inundated surface in the North (flooded) section had risen slightly to $90 \%$, whereas during this time only $67 \%$ of the Central (drained) section was inundated due to the lower water table and moderate microtopography.

In response to the manipulation treatment during the growing season, our simulated continuation of average thaw depth into the autumn showed variation among the treatments (Fig. 3). At the beginning of the autumn study period on 19 August, average thaw was deepest in the North (flooded) section at $34 \mathrm{~cm}( \pm 4.5$ s.d.), intermediate in the South (intermediate) section at $29 \mathrm{~cm}( \pm 4$ s.d.), and shallowest in the Central (drained) section at $26 \mathrm{~cm}( \pm 3.5$ s.d.). All mean differences were highly significant $(p<0.001)$. Our modeled thaw estimated this trend to continue until maximum thaw was reached on 19 September, when we estimated the North section reached an average thaw of $38 \mathrm{~cm}$, the South section to $34 \mathrm{~cm}$, and the Central section to $29 \mathrm{~cm}$.

Soil temperatures dropped rapidly toward $0{ }^{\circ} \mathrm{C}$ beginning 19 September and the active layer subsequently began freezing. Temperature profile measurements (Fig. 4a and b) showed that the top-down and bottom-up freezing fronts in the North (flooded) section lagged behind those of the Central (drained) section. On 21 October (the last date of nonrejected fluxes), we estimated that a $\sim 6 \mathrm{~cm}$ thick layer of soil in the Central section remained completely unfrozen compared to about $23 \mathrm{~cm}$ in the North section (Fig. 3).

Similar to the freezing front behaviour, declines in unfrozen soil moisture due to soil freezing in the North (flooded) section lagged behind the Central (drained) section (Fig. $4 \mathrm{c}$ and d). Dates at which the $0-10 \mathrm{~cm}, 0-30 \mathrm{~cm}$, and 20-30 cm unfrozen soil moistures approached minimum levels were 31 October, 10 November, and 13 November, respectively, in the Central section compared to 7 November, 18 November, and 14 November, respectively, in the North section.

\subsection{Eddy covariance $\mathrm{CH}_{4}$ flux}

In the early autumn (until 7 September), $\mathrm{CH}_{4}$ emissions were similar between the North (flooded) and South (intermediate) sections (Fig. 5a) and showed no temporal trend. The North section $\mathrm{CH}_{4}$ flux averaged 33.7 ( \pm 2.6 s.d.) $\mathrm{mg}$ $\mathrm{CH}_{4} \mathrm{~m}^{-2} \mathrm{~d}^{-1}$ during this time, only $3.3 \mathrm{mgCH}_{4} \mathrm{~m}^{-2} \mathrm{~d}^{-1}$ greater than the South section on average (South average: $30.4 \pm 3.3$ s.d. $\mathrm{mg} \mathrm{CH}_{4} \mathrm{~m}^{-2} \mathrm{~d}^{-1}$ ). A paired t-test comparing the daily average $\mathrm{CH}_{4}$ flux between North (flooded) and South (intermediate) sections indicated this difference was not statistically significant $(p=0.11)$.
$\mathrm{CH}_{4}$ fluxes in the North (flooded) section generally continued at early autumn levels until 21 September after top-down soil freezing had begun, at which point emissions notably declined. There were, however, short periods of increased $\mathrm{CH}_{4}$ emissions, up to $96 \mathrm{mg} \mathrm{CH}_{4} \mathrm{~m}^{-2} \mathrm{~d}^{-1}$, which appeared to coincide with high wind speed events and were noted even after the soil surface was frozen. Central (drained) section $\mathrm{CH}_{4}$ fluxes, although significantly lower than the North section, exhibited the same trend, averaging 13.3 ( \pm 4 s.d.) $\mathrm{mg} \mathrm{CH}_{4} \mathrm{~m}^{-2} \mathrm{~d}^{-1}$ prior to soil freezing and declining thereafter, although the decline in Central section $\mathrm{CH}_{4}$ flux immediately after soil freezing began was not as pronounced as the North section. The Central section also exhibited peaks in $\mathrm{CH}_{4}$ emission that corresponded with high winds, but the peaks were lower in magnitude than those of the North (flooded) section. During the period of concurrent North-Central $\mathrm{CH}_{4}$ flux measurements (9 September-25 October), the North (flooded) section emitted $\mathrm{CH}_{4}$ at approximately 2.4 times the rate of the Central (drained) section and this difference was statistically significant (paired t-test on daily averaged fluxes, $p<0.001$ ). Both the North and Central sections continued to emit small amounts of $\mathrm{CH}_{4}$ at the end of the study period $\left(\sim 14 \mathrm{mg} \mathrm{CH}_{4} \mathrm{~m}^{-2} \mathrm{~d}^{-1}\right.$ in the North and $\sim 7.5 \mathrm{mg} \mathrm{CH}_{4} \mathrm{~m}^{-2} \mathrm{~d}^{-1}$ in the Central), even though the soil temperature profiles indicated that the top-down freezing front was deeper than $5 \mathrm{~cm}$ in the North section and deeper than $10 \mathrm{~cm}$ in the Central section.

Because of the large proportion of rejected half-hourly measurements, we were not able to gap-fill $\mathrm{CO}_{2}$ flux measurements in order to statistically compare daily averages of $\mathrm{CO}_{2}$ and $\mathrm{CH}_{4}$ eddy covariance flux. However, we did not notice a strong relationship between half-hourly $\mathrm{CO}_{2}$ and $\mathrm{CH}_{4}$ fluxes during the autumn.

\subsection{Relationship between environmental variables and autumn $\mathrm{CH}_{4}$ flux}

For each manipulation section, we performed a correlation analysis to identify the main environmental drivers of variation in average daily $\mathrm{CH}_{4}$ flux during the autumn. For the North (flooded) section, we found that $\mathrm{CH}_{4}$ flux was most strongly correlated with unfrozen soil moisture in the top $30 \mathrm{~cm}$ in an exponential relationship $(r=0.74, p<0.001$, Fig. 6a). This relationship represented the decline in $\mathrm{CH}_{4}$ emissions as soil water in the active layer froze. We also found a moderate correlation between $\mathrm{CH}_{4}$ flux and friction velocity, $u^{*},(r=0.48, p=0.004$, Fig. $6 \mathrm{~b})$, which corresponded to increased emissions during strong winds. In a multiple regression between environmental variables and $\log \left(\mathrm{CH}_{4}\right.$ flux $)$, unfrozen soil moisture in the top $30 \mathrm{~cm}$ and friction velocity explained $62 \%$ of the variability $(F=24.7$, $p<0.001$ ). Adding other variables to the regression model only increased $R^{2}$ by a few percent.

For the Central (drained) section, daily average $\mathrm{CH}_{4}$ flux was most strongly correlated with $u^{*}(r=0.66, p<0.001$; 


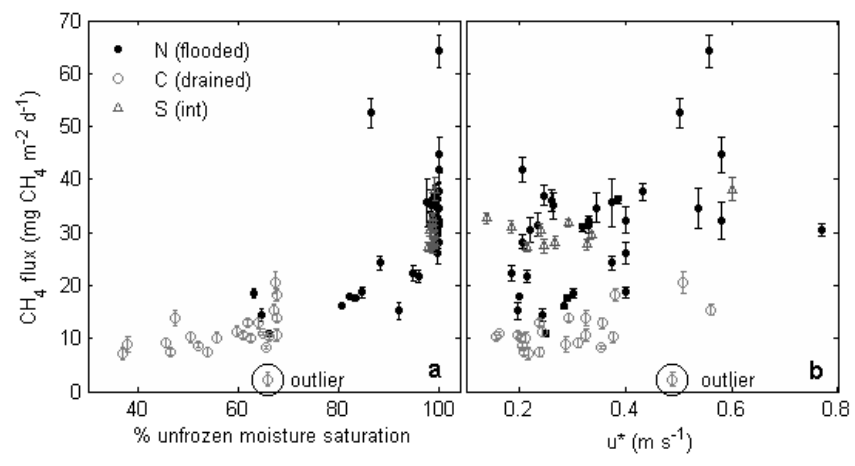

Fig. 6. Relationship between daily average eddy covariance $\mathrm{CH}_{4}$ flux and unfrozen moisture saturation in the top $30 \mathrm{~cm}$ of soil (a), and the relationship between eddy covariance $\mathrm{CH}_{4}$ flux and friction velocity (b). The circled point was an outlier removed from the correlation analysis. Error bars represent standard error of the mean.

Fig. 6b), followed closely by an exponential relationship with unfrozen soil moisture in the top $30 \mathrm{~cm}(r=0.62, p=0.002$, Fig. 6a). In a multiple regression model of $\log \left(\mathrm{CH}_{4}\right.$ flux $)$ and environmental parameters, $u^{*}$ and unfrozen moisture in the top $30 \mathrm{~cm}$ explained $60 \%$ of the variability, and no other environmental variables were found to significantly add to this model.

Although the period of measurement for the South (intermediate) section was short, we found the strongest correlation to occur between daily average $\mathrm{CH}_{4}$ flux and the square of the wind speed $(r=0.76, p=0.01)$, which was similar to the relationships between $u^{*}$ and $\mathrm{CH}_{4}$ flux observed for the North and Central sections (wind speed is highly correlated with $u^{*}$ ) (Fig. 6b). No other environmental variable added significantly to the variability explained by wind speed $\left(R^{2}=58 \%\right)$.

Comparison of the expected fluxes from the regression models with measured fluxes (Fig. 7) showed that the North section regression underestimated the increase in $\mathrm{CH}_{4}$ flux during windy periods (wind speed is highly correlated with $\left.u^{*}\right)$. In the half-hourly data, we noticed a $u^{*}$ threshold of about $0.4 \mathrm{~m} \mathrm{~s}^{-1}$ above which the variance in $\mathrm{CH}_{4}$ flux for the North and Central sections increased (there was not enough data at high turbulence to evaluate this for the South section) and the relationship between $u^{*}$ and $\mathrm{CH}_{4}$ flux for the North section became increasingly non-linear. In the North section, the regression model overestimated $\mathrm{CH}_{4}$ fluxes after soil freezing began (except for windy periods), failing to capture the immediate decline in fluxes as the surface froze. There was no substantial bias in the regression residuals for the Central or South sections.

\subsection{Chamber measurements}

Although our chamber measurements of $\mathrm{CH}_{4}$ flux at the $\mathrm{BE}$ were taken over a few days prior to soil freezing during the autumn of 2007 , we noted spatial patterns at the

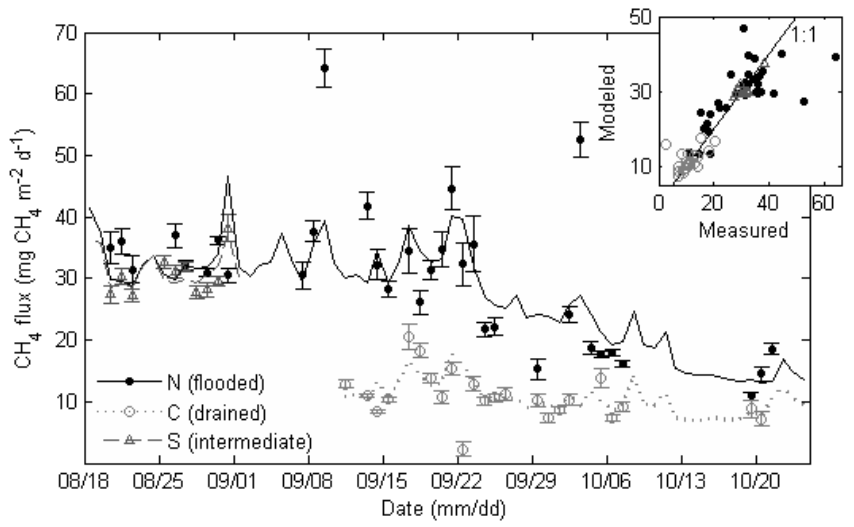

Fig. 7. Measured daily average $\mathrm{CH}_{4}$ fluxes (points) along with modeled fluxes derived from multiple regression results (lines). The inset plot compares measured and modeled fluxes to a 1:1 relationship (North model $R^{2}=62 \%, p<0.001$; Central model $R^{2}=60 \%$, $p<0.001$, South model $R^{2}=58 \%, p=0.01$ ).

small chamber scale $(<1 \mathrm{~m}$ diameter $)$ which have relevance to the $\sim 100 \mathrm{~m}$ scale of the eddy covariance measurements of 2009. Figure 8a shows the relationship between soil moisture and chamber $\mathrm{CH}_{4}$ flux. The pattern of $\mathrm{CH}_{4}$ emission showed no relationship with soil moisture $\left(R^{2}=0\right.$; $p=0.89$ ) until the soil was completely saturated (water table at or above the surface), at which point there was a very large range of emissions from just over $10 \mathrm{mg} \mathrm{CH}_{4} \mathrm{~m}^{-2} \mathrm{~d}^{-1}$ to $200 \mathrm{mg} \mathrm{CH}_{4} \mathrm{~m}^{-2} \mathrm{~d}^{-1}$. This was in contrast to the strong relationship between $\mathrm{CH}_{4}$ emission and soil moisture observed for the eddy covariance data of 2009 (Fig. 6a). However, the chamber data address how spatial variation in inundation state at the microsite level informs upon ecosystemintegrated $\mathrm{CH}_{4}$ flux, whereas the soil moisture- $\mathrm{CH}_{4}$ flux relationship in the eddy covariance data represents the effect of the soil freezing process.

Inundated sites (soil moisture $100 \%$ saturated) showed a much higher average chamber $\mathrm{CH}_{4}$ flux (78.4 \pm 16.4 s.e. $\mathrm{mg} \mathrm{CH}_{4} \mathrm{~m}^{-2} \mathrm{~d}^{-1}$ ) than unsaturated sites $\left(25.3 \pm 6.3\right.$ s.e. $\left.\mathrm{mg} \mathrm{CH}_{4} \mathrm{~m}^{-2} \mathrm{~d}^{-1}\right)$ and were up to 8 times higher than the average $\mathrm{CH}_{4}$ emission of unsaturated sites. This pattern was seen for both the North and Central sections, which for this year were the only sections with saturated sites during the autumn (the water table in the South section was lower than the North and Central sections in 2007, Olivas et al., 2010). A two-sample t-test comparing unsaturated $(n=19)$ and saturated $(n=17)$ sites showed the difference in $\mathrm{CH}_{4}$ emission was highly significant ( $p=0.006$, unequal variances). Unsaturated sites in the North and Central sections tended to be polygon rims (see Fig. 1 inset), and grouping sites which were clearly polygon rims $(n=7)$ or the centers of low-center polygons $(n=15)$ in these sections also showed a highly significant difference ( $p=0.007$ ), with polygon rims showing the lowest $\mathrm{CH}_{4}$ emission. 

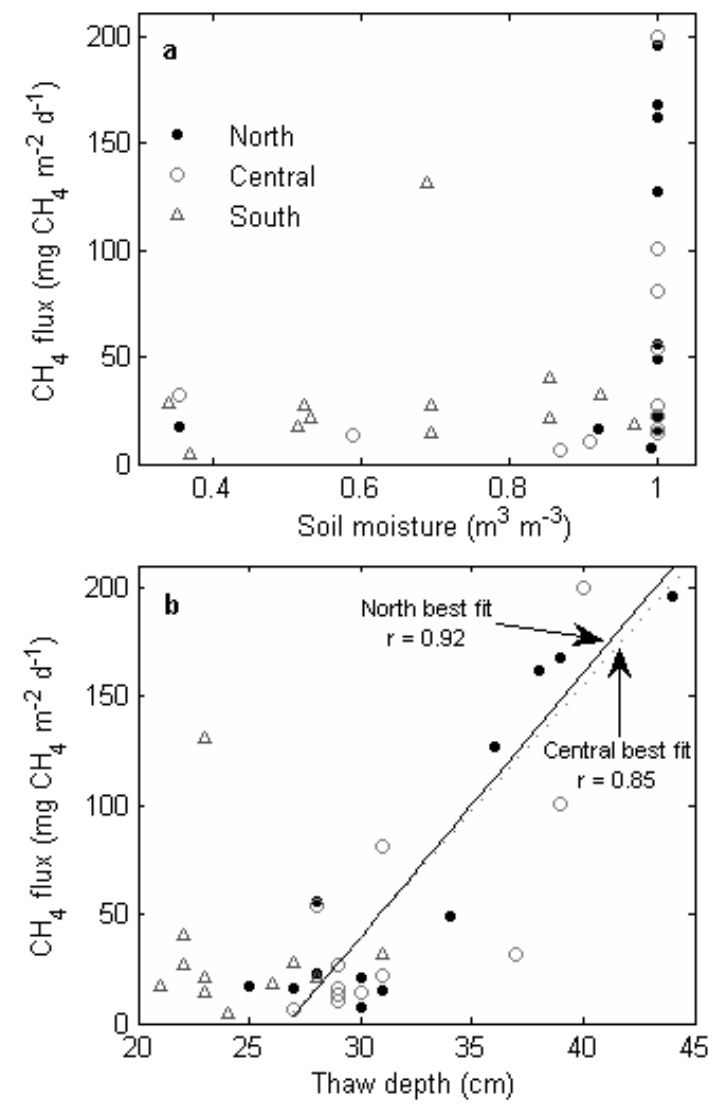

Fig. 8. Relationship between chamber measurements of $\mathrm{CH}_{4}$ flux and soil moisture (a) and thaw depth (b) taken between 13 and 18 September 2007. Note that in this year, the South section showed a much lower water table than the North and Central sections during the growing season. Lines in (b) show the best fit between $\mathrm{CH}_{4}$ flux and thaw depth for sites with water tables at or above the surface (only in the North and Central sections).

Average chamber $\mathrm{CH}_{4}$ fluxes measured in each section between 13 and 18 September in 2007 were as follows: North section $\mathrm{CH}_{4}$ flux averaged $71.4 \pm 20.4$ s.e. $\mathrm{mg} \mathrm{CH}_{4} \mathrm{~m}^{-2} \mathrm{~d}^{-1}$, corresponding with $75 \%$ of the sites saturated. Central section $\mathrm{CH}_{4}$ flux averaged $48.0 \pm 16.3$ s.e. $\mathrm{mg} \mathrm{CH}_{4} \mathrm{~m}^{-2} \mathrm{~d}^{-1}$, corresponding with $67 \%$ of the sites saturated. Finally, the South section $\mathrm{CH}_{4}$ flux averaged $31.7 \pm 9.4$ s.e. $\mathrm{mg} \mathrm{CH}_{4} \mathrm{~m}^{-2} \mathrm{~d}^{-1}$, corresponding with none of the sites saturated.

The large range of emissions when the water table was at or above the surface was further explained by a positive relationship with thaw depth (Fig. 8b). For sites with water tables above the surface in the North and Central sections, thaw depth explained $85 \%(p<0.001)$ and $72 \%(p=0.007)$, respectively, of the variability in $\mathrm{CH}_{4}$ emission. There was no observed relationship between chamber-measured soil $\mathrm{CO}_{2}$ respiration and $\mathrm{CH}_{4}$ flux.

After the chamber measurements (18 September 2007), air temperature dropped below $0{ }^{\circ} \mathrm{C}$ and a thin layer of ice

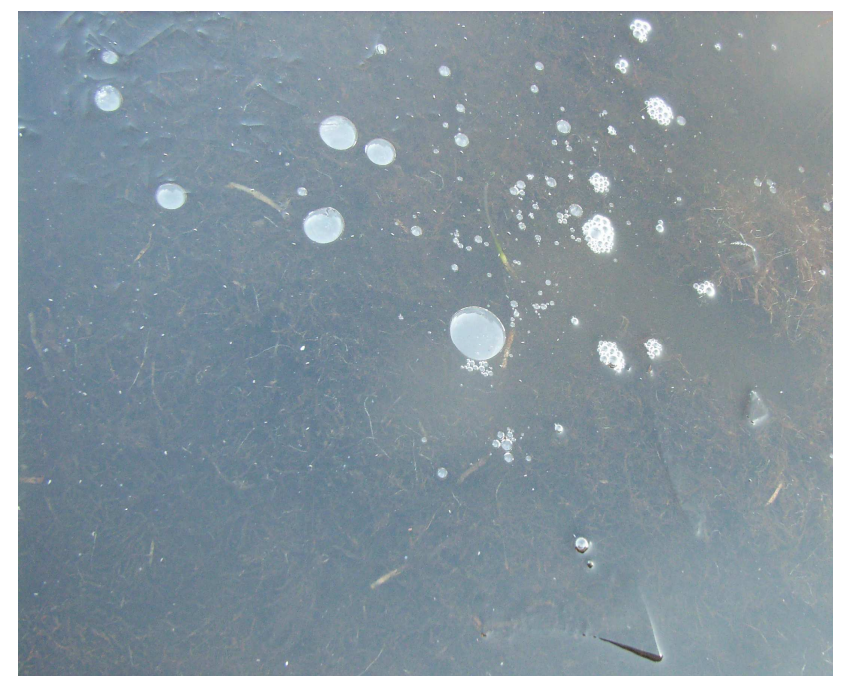

Fig. 9. $\mathrm{CH}_{4}$ bubbles trapped under a newly frozen water surface in an inundated polygon center in the North section on 18 September 2007. A sampled bubble showed a $\mathrm{CH}_{4}$ concentration of 804 parts per thousand.

formed over standing water in low-center polygons. We observed bubbles to accumulate under this ice at several locations (Fig. 9), and a sampled bubble showed a $\mathrm{CH}_{4}$ concentration of 804 parts per thousand, indicating that $\mathrm{CH}_{4}$ ebullition is a mechanism of $\mathrm{CH}_{4}$ release at this site.

\subsection{Autumn $\mathrm{CH}_{4}$ emission budget}

In order to obtain rough estimates for the amount of $\mathrm{CH}_{4}$ emitted outside the typical summer measurement period, we used our regression models (Fig. 7) to gap-fill missing eddy covariance measurements of daily $\mathrm{CH}_{4}$ flux for the North (flooded) and Central (drained) sections of the BE in 2009. We loosely define the autumn as late August to late October, which follows the convention adopted by Euskirchen et al. (2006) involving the transition from positive to negative near-surface soil temperatures. However, in order for the estimates for the North (flooded) and Central (drained) sections to be comparable, we limited our estimates to the concurrent measurement period (9 September to 25 October). For the 46 days between 9 September and 25 October, we estimated that the North (flooded) section emitted $1.1 \mathrm{~g} \mathrm{CH}_{4} \mathrm{~m}^{-2}$ while the Central (drained) section emitted $0.5 \mathrm{~g} \mathrm{CH}_{4} \mathrm{~m}^{-2}$. We did not estimate the autumn $\mathrm{CH}_{4}$ flux in the South (intermediate) section due to the lack of data during the freezing period.

We estimated a 100-day growing season total of $2.4 \mathrm{~g} \mathrm{CH}_{4} \mathrm{~m}^{-2}$ from average eddy covariance measurements taken at the BE during June and July of 2007 (Zona et al., 2009). The year 2007 was a warm and dry year for Barrow, and average water tables and thaw depths at the BE during the growing season of 2007 were similar to the Central (drained) section in the growing season of 2009, although 
soil temperatures at $10 \mathrm{~cm}$ depth were generally warmer in 2007. Average emissions at the BE at the end of July 2007 were similar to emissions in the North (flooded) section at the beginning of our 2009 autumn measurement period (19 August). Therefore, we think our 2009 autumn estimate for the Central (drained) section presents a probably conservative comparison to the growing season estimate of 2007, amounting to $21 \%$ of the 100-day $\mathrm{CH}_{4}$ flux.

We also compared our North (flooded) autumn $\mathrm{CH}_{4}$ flux estimate of 2009 to an estimate we calculated from growing season chamber $\mathrm{CH}_{4}$ fluxes taken by Rhew et al. (2007) during 2005 at the BE prior to the water table manipulation. The growing season of 2005 was climatically very similar to 2009 and conditions at the BE were mostly wet or flooded. From the average June and August measurements by Rhew et al. (2007), we calculated a 100-day growing season $\mathrm{CH}_{4}$ flux estimate of $4.4 \mathrm{~g} \mathrm{CH}_{4} \mathrm{~m}^{-2}$. Comparing our North (flooded) section autumn emission of $1.1 \mathrm{~g} \mathrm{CH}_{4} \mathrm{~m}^{-2}$ to this wet/flooded growing season estimate yielded a $\sim 25 \%$ autumn contribution, which is very similar to the $21 \%$ we calculated for the drier tundra scenario.

\section{Discussion}

\subsection{Controls on $\mathrm{CH}_{4}$ flux}

We have presented some of the first ecosystem-scale measurements of autumn $\mathrm{CH}_{4}$ flux in the Arctic under manipulated moisture conditions. The $\mathrm{CH}_{4}$ flux rates we measured in the North (flooded) and South (intermediate) sections during the early autumn of 2009 were lower than growing season values measured at this site (Zona et al., 2009), as well as chamber measurements in the vicinity of Barrow (von Fischer et al., 2010) and eddy covariance measurements in similar tundra on the Arctic Coastal Plain of Alaska (Vourlitis et al., 1994). Our emissions were substantially lower than early autumn chamber-based measurements from arctic wetland tundra in northern Siberia (Corradi et al., 2005; Merbold et al., 2009), but were quite similar to measurements in Siberia and Greenland using eddy covariance (Friborg et al., 2000; Wille et al., 2008; Sachs et al., 2008) and chambers prior to soil freezing (Mastepanov et al., 2008; Sachs et al., 2010). Our early autumn 2009 eddy covariance measurements were generally lower on average than our chamber measurements between 13 and 18 September 2007. This could be due to the fact that chamber measurements were made in a different year with different climatic conditions. It could also be connected to a localized increase in $\mathrm{CH}_{4}$ ebullition (e.g. Fig. 9) instigated by the slight disturbance to the surface by the chamber measurement. Chamber measurements of 2007 showed similar magnitude and variation in $\mathrm{CH}_{4}$ flux at the microsite level to the Sachs et al. (2010) study for which eddy covariance measurements at the same site (Sachs et al., 2008; Wille et al., 2008) were similar to ours.

The manipulation during the 2009 growing season at the BE successfully differentiated the water tables in the North (flooded), Central (drained), and South (intermediate) sections, and we simulated that significant differences continued in the autumn. Although the average water table in the North (flooded) section was well above the South (intermediate) section in the early autumn, North and South $\mathrm{CH}_{4}$ efflux were very similar. Thus, there was no reduction in $\mathrm{CH}_{4}$ flux with increased inundation depth, which is contrary to previous observations at this site (Zona et al., 2009) and noted by a few other authors (Sachs et al., 2010; Jauhiainen et al., 2005). However, our autumn results align with the work of authors who found null or positive relationships between inundation depth and $\mathrm{CH}_{4}$ emission (e.g. Morrissey and Livingston, 1992; Heyer et al., 2002; Parmentier et al., 2011).

A higher water table above the surface (greater inundation depth) increases the diffusive resistance between the soil surface and the atmosphere and also may cover the areas of a plant where $\mathrm{CH}_{4}$ diffusing through aerenchyma exits. However, studies investigating plant-mediated transport differ in their conclusions on the portions of the plant which transport $\mathrm{CH}_{4}$ to the atmosphere. For example, Kelker and Chanton (1997) found that virtually all $\mathrm{CH}_{4}$ was released in the lower $15 \mathrm{~cm}$ of the plant while Schimel (1995) concluded that leaves were the dominant pathway of $\mathrm{CH}_{4}$ release. Therefore, it has been suggested that the differing conclusions of these studies may be a result of other factors such as plant phenology, $\mathrm{CH}_{4}$ concentration in pore water, and soil temperature (Kutzbach et al., 2004), all which differ substantially between the early growing season and the autumn, and may explain why deeper inundation was found to inhibit $\mathrm{CH}_{4}$ emission in the early season (Zona et al., 2009) but not in the late season (this study).

Based on our chamber measurements during the autumn of 2007 and knowledge of the site, we propose the similar $\mathrm{CH}_{4}$ emissions between the North (flooded) and South (intermediate) sections were due to the greater degree of polygon development in the North section (Fig. 1), which resulted in increased inundation depth in localized areas but only small changes in the proportion of inundated landscape. Greater polygon development implies that polygon rims may remain above the water table even if the average water table is well above the surface (as in the North section). They form drier microsites that presented lower $\mathrm{CH}_{4}$ emission. On the other hand, even a small increase in average water table above the surface could result in nearly complete inundation in a landscape with very low polygon development (as in the South section, Fig. 1). Thus, even though the water table in the North section was on average $\sim 8 \mathrm{~cm}$ higher than the South during the early autumn, similar proportions of the landscape were inundated. Our chamber observations showed a large increase in $\mathrm{CH}_{4}$ emission when the water table was at or above the surface, which agrees with many previous chamber 
studies (e.g. Bubier et al., 1993, 1995; von Fischer et al., 2010) due to greater anaerobic/aerobic respiration ratio in the soil column and substantial reduction in microbial $\mathrm{CH}_{4}$ oxidation. The landscape-level $\mathrm{CH}_{4}$ emission should be related to the proportional coverage of the surface type with the greatest emission rate (Forbrich et al., 2011; Parmentier et al., 2011), and since the proportions of inundated surface were nearly identical in the North and South this explains why emissions were similar.

The significantly reduced $\mathrm{CH}_{4}$ emissions in the Central (drained) section compared to the North (flooded) section was also consistent with the relative proportions of inundated surface, which was significantly lower in the Central section due to moderate polygon development and an average water table only a few $\mathrm{cm}$ above the surface, leaving a significantly higher proportion of sites above the water table. The large Siberian tundra drainage experiment by Merbold et al. (2009) also showed a late summer/early autumn increase in water table to just above the surface in their drained treatment. At this point, the $\mathrm{CH}_{4}$ emissions in their drained treatment notably increased from near-zero levels to the general range of pre-freeze emissions in our Central (drained) section, although the emissions in their inundated control where still much higher.

We observed no clear relationship between our half-hourly $\mathrm{CO}_{2}$ and $\mathrm{CH}_{4}$ eddy covariance fluxes in 2009 , nor between chamber measurements of soil $\mathrm{CO}_{2}$ respiration and $\mathrm{CH}_{4}$ flux in 2007. This result was consistent with the observed high availability of dissolved $\mathrm{Fe}$ (III) in pore water at the BE, and its importance as an alternative electron acceptor in the production of respired $\mathrm{CO}_{2}$ under anaerobic conditions (Lipson et al., 2010). Thus, the significant capability of this ecosystem for anaerobic respiration of $\mathrm{CO}_{2}$ may mask the small increase in aerobic $\mathrm{CO}_{2}$ respiration for a few centimeters of soil above the water table.

The importance of thaw depth as a control on $\mathrm{CH}_{4}$ emission (Fig. 8b) is in agreement with previous studies (e.g. Friborg et al., 2000; von Fischer et al., 2010; Zona et al., 2009). It is well-documented that a greater amount of unfrozen water increases heat conduction to deeper soil layers and deepens thaw during the growing season (e.g. Drew et al., 1958; Hinzman et al., 1991; Shiklomanov et al., 2010). Deeper thaw due to greater soil heat conduction in wetter conditions is supported at our site by the strong relationship between cumulative ground heat flux and thaw depth (see Fig. B2 in Supplement). Soils in this region maintain high organic carbon contents throughout the top $100 \mathrm{~cm}$ of soil (Bockheim et al., 1999), therefore a larger volume of unfrozen soil provides a greater amount of organic carbon available for decomposition (Vourlitis et al., 1993; Zona et al., 2009). $\mathrm{CH}_{4}$ fluxes measured by chambers in this study showed that much of the variation in $\mathrm{CH}_{4}$ flux at water tables above the surface could be explained by thaw depth, supporting that the greater active layer thickness in the North (flooded) section, in conjunction with greater inundation depth and greater proportion of inundated landscape, contributed to the more than double ecosystem-scale $\mathrm{CH}_{4}$ emissions compared to the Central (drained) section. The slightly thicker active layer in the North section compared to the South (intermediate) may be why the North section emitted $\mathrm{CH}_{4}$ at a slightly elevated rate (although not statistically significant) compared to the South section in the early autumn of 2009 , even though we estimated the South section to have a slightly greater coverage of inundated surface.

The strong correlation we found between ecosystem-level (eddy covariance) $\mathrm{CH}_{4}$ flux and unfrozen moisture saturation in the top $30 \mathrm{~cm}$ of soil indicated the declining availability of unfrozen water (and therefore anaerobic respiration at inundated sites) during the soil freeze period (Panikov et al., 2006; Oechel et al., 1997), which corresponded with declines in landscape-scale $\mathrm{CH}_{4}$ flux for both the North (flooded) and Central (drained) sections. The eddy covariance measurements presented by Wille et al. (2008) for a comparable site in the Lena River Delta, Siberia extended to a similar point in the cold season and also showed a gradual decline in emissions after soil freezing began. At the end of the study period, the North section continued to emit higher levels of $\mathrm{CH}_{4}$ than the Central $\left(\sim 14\right.$ vs. $\sim 7.5 \mathrm{mg} \mathrm{CH}_{4} \mathrm{~m}^{-2} \mathrm{~d}^{-1}$, respectively), consistent with the lag in freezing front progression and greater unfrozen water still present at inundated sites in the North section. Thus, the greater inundation depth and associated deeper thaw in the North section resulted in longer availability of unfrozen water and elevated $\mathrm{CH}_{4}$ emissions into the early winter compared to better drained tundra.

Soil temperature is known to strongly control microbial activity and $\mathrm{CH}_{4}$ flux in arctic tundra (e.g. Morrissey and Livingston, 1992; Christensen et al., 2003; Merbold et al., 2009; Wagner et al., 2007). A strong dependence of $\mathrm{CH}_{4}$ emission on soil temperature was indeed noted during the growing season at this site (Zona et al., 2009), so we expected similar results for the autumn. However, we did not find that soil temperature helped to explain the variability in autumn $\mathrm{CH}_{4}$ emissions. We do not think that the lack of an influential relationship between soil temperature and $\mathrm{CH}_{4}$ flux is due to a diminished response of this system to soil temperature during the autumn. Rather, the generally high soil moistures and associated latent heat storage caused a long soil freezing period where soil temperatures were restricted to near $0^{\circ} \mathrm{C}$ for a large proportion of the study. As a result, our observations show that the autumn transition in $\mathrm{CH}_{4}$ emissions is more controlled by the availability of unfrozen water at inundated sites during soil freeze-up than soil temperature, and by large atmospheric turbulence favouring the escape of $\mathrm{CH}_{4}$ from freezing soil layers.

The positive relationship we observed between friction velocity (strongly correlated with wind speed) and $\mathrm{CH}_{4}$ emission has been noted before for other eddy covariance studies in arctic and sub-arctic tundra (Fan et al., 1992; Sachs et al., 2008; Wille et al., 2008). Greater atmospheric turbulence disturbs emergent vegetation which may facilitate ebullition, 
the instantaneous release of $\mathrm{CH}_{4}$ bubbles trapped within the soil or on surfaces below the water table (e.g. Fig. 9). Morrissey and Livingston (1992) observed that winds of approximately $10 \mathrm{~m} \mathrm{~s}^{-1}$ or greater instigated $\mathrm{CH}_{4}$ ebullition in Alaskan arctic tundra and several studies have noted the importance of ebullition as a $\mathrm{CH}_{4}$ emission pathway in temperate and arctic wetlands (e.g. Goodrich et al., 2011; Walter et al., 2006; Desyatkin et al., 2009). We did not find that atmospheric pressure improved the $\mathrm{CH}_{4}$ flux variability explained by soil moisture and $u^{*}$. However, high wind events corresponded to relative drops in pressure (Fig. 5c), which along with $u^{*}$ has been suggested to be one of the main triggers of $\mathrm{CH}_{4}$ ebullition (Sachs et al., 2008).

Higher friction velocities also increase the turbulent transfer of $\mathrm{CH}_{4}$ across the air-water interface, which has been suggested to be an important pathway for sites with greater surface water coverage (Fan et al., 1992; Wille et al., 2008; Sachs et al., 2008). The North (flooded) section showed a greater response to high wind events, and fitting a quadratic relationship observed in the latter studies to our half-hourly fluxes from the North section showed good correspondence. The sharper reduction in $\mathrm{CH}_{4}$ emissions for the North (flooded) section compared to the Central (drained) section upon freezing of the surface may be due to the reduction in this release mechanism and could explain the failure of the regression model to adequately capture the immediate drop in $\mathrm{CH}_{4}$ emissions at the onset of top-down soil freezing in the North section. As observed by Sachs et al. (2008), a correlation between $u^{*}$ and $\mathrm{CH}_{4}$ flux remained after the surface layer had frozen, supporting the suggested increase in $\mathrm{CH}_{4}$ transport through vegetation aerenchyma with greater turbulence.

At this site we found no evidence for an autumn $\mathrm{CH}_{4}$ pulse during soil freeze-up, which has been observed using chamber measurements in northern Greenland (Mastepanov et al., 2008). We cannot be certain that a pulse did not occur at our site, since the soil profile had not completely frozen by the end of our measurements and the mechanism proposed by Mastepanov et al. (2008) was the squeezing out of $\mathrm{CH}_{4}$ as soil freezing progressed. However, the Mastepanov et al. (2008) study showed steadily increasing $\mathrm{CH}_{4}$ emissions from the onset of soil freezing until the top-down freezing front reached $10 \mathrm{~cm}$ (after which was the large pulse), which is in contrast to the generally downward trend we observed at the BE.

\subsection{Seasonal emissions}

We estimated that autumn season $\mathrm{CH}_{4}$ emission added 21$25 \%$ to the 100-day growing season in which $\mathrm{CH}_{4}$ emissions are typically measured. Therefore, while the autumn-winter transition exhibits dwindling $\mathrm{CH}_{4}$ emissions, it still represents a significant source of $\mathrm{CH}_{4}$ at this site important to the annual budget. The contribution of autumn emissions to the annual $\mathrm{CH}_{4}$ budget at the $\mathrm{BE}$ is more relevant than other sites with a more pronounced seasonal pattern (e.g. high summer emissions and sharper late summer declines, Merbold et al., 2009; Whalen and Reeburgh, 1988). Whalen and Reeburgh (1988) showed that only $10 \%$ of the mean annual $\mathrm{CH}_{4}$ flux for high summer-emitting sites occurred outside the thaw period, which is much lower than our estimate for the autumn only. However, our estimate of the autumn contribution is similar to the site of the Wille et al. (2008) study which showed only slightly more elevated growing season emissions compared to the autumn and a gentle decline after soil freezing began, such that they estimated that winter emissions accounted for $35 \%$ of the annual flux. In a year-round study of $\mathrm{CH}_{4}$ flux in a Swedish sub-arctic mire, JackowiczKorczynski et al. (2010) estimated the autumn season contributed $12-21 \%$ of annual emissions, which is similar to our estimate. Contrasting seasonal estimates support the need for further studies outside the growing season to develop accurate annual $\mathrm{CH}_{4}$ budgets for arctic regions.

Since moderate amounts of $\mathrm{CH}_{4}$ were still being emitted in both the North (flooded; $\sim 14 \mathrm{mg} \mathrm{CH}_{4} \mathrm{~m}^{-2} \mathrm{~d}^{-1}$ ) and Central (drained; $\sim 7.5 \mathrm{mg} \mathrm{CH}_{4} \mathrm{~m}^{-2} \mathrm{~d}^{-1}$ ) treatments of the manipulation when our measurements ended, and unfrozen soil moistures in the top $30 \mathrm{~cm}$ did not decline to near winter levels until mid-November, we suspect that $\mathrm{CH}_{4}$ production continued a gradual descent until near this time. In yearround observations of Alaskan sub-arctic tundra (Whalen and Reeburgh, 1988, 1992), $\mathrm{CH}_{4}$ emissions did not decline to near-winter lows until soil temperatures were below -3 to $-4^{\circ} \mathrm{C}$. High unfrozen moisture contents are known to persist at soil temperatures below $0{ }^{\circ} \mathrm{C}$, and are especially high above $-1{ }^{\circ} \mathrm{C}$ (Romanovsky and Osterkamp, 2000). As cooling of the active layer is largely restrained until most of the latent energy stored in surface and soil water is released by freezing (Romanovsky and Osterkamp, 2000), soil temperatures also remain more favourable for microbial activity until unfrozen moisture declines to near-winter levels and strong cooling ensues. The greater depth and fraction of inundated landscape in the North (flooded) section resulted in a prolonging of this process, and we assumed $\mathrm{CH}_{4}$ production continued during this time. Therefore, we hypothesize that increased flooding at the local level due to the melting of massive ice wedges (Jorgenson et al., 2006) or permafrost degradation (Smith et al., 2005) is likely not only to increase $\mathrm{CH}_{4}$ emission due to more anaerobic conditions but also to extend elevated $\mathrm{CH}_{4}$ emissions later into the winter. This may result in greater spring emissions, as the frozen surface layer may trap $\mathrm{CH}_{4}$ produced in the autumn and early winter (e.g. Fig. 9) until it can be released when the surface thaws the following spring (Heyer et al., 2002).

Satellite observations and model simulations show that present and future increases in growing season length and associated increases in net ecosystem productivity are primarily due to earlier thaw (Euskirchen et al., 2006), but studies of arctic lakes show evidence that later freeze-up is also occurring and forecasted to continue (Callaghan et al., 
2010; Brown and Duguay, 2011). Therefore, as light levels and photosynthesis decrease toward zero in the autumn, prolonged $\mathrm{CH}_{4}$ emission from areas of warm and wet tundra may become even more relevant. Further research measuring non-summer ecosystem-scale flux measurements across the Circumpolar Arctic and under variable tundra moisture conditions are needed to test and quantify this effect.

\section{Conclusions}

This study showed that $\mathrm{CH}_{4}$ emission during the autumn season is an important component to the annual $\mathrm{CH}_{4}$ budget from arctic tundra on the Arctic Coastal Plain of Alaska. We found that the soil water freezing progression, rather than temperature, controlled the decline in $\mathrm{CH}_{4}$ emission during the autumn transition, and turbulence was important in releasing $\mathrm{CH}_{4}$ from this ecosystem. Increased polygon development limited increases in surface water coverage in our flooded treatment and therefore limited increases in ecosystem $\mathrm{CH}_{4}$ emission rate compared to an intermediate water table with less polygon development. However, increased inundation prolonged the availability of unfrozen soil moisture during the freeze-up period and therefore has important implications for extending $\mathrm{CH}_{4}$ emissions longer into the winter season. Further research should expand ecosystem-scale $\mathrm{CH}_{4}$ flux measurements to more locations around the Circumpolar Arctic and extend them outside the growing season to promote more accurate annual arctic $\mathrm{CH}_{4}$ budgets and a greater understanding of non-summer $\mathrm{CH}_{4}$ dynamics under variable moisture conditions at the ecosystem-level.

\section{Supplementary material related to this article is available online at: http://www.biogeosciences.net/9/ 1423/2012/bg-9-1423-2012-supplement.pdf.}

Acknowledgements. We thank LI-COR Biosciences for the opportunity to use the newly developed LI-7700 $\mathrm{CH}_{4}$ analyser as well as their technical assistance in doing so. We also thank the Barrow Arctic Science Consortium and CH2M Hill Polar Services for logistic support, as well as the many undergraduates and personnel who contributed to maintaining the BE site. We also thank the four anonymous reviewers for their helpful comments and suggestions to improve this manuscript. This research was made possible by support from the National Science Foundation Office of Polar Programs (Grant No. OPP-0436177), the US Department of Energy National Institute for Climate Change Research (Grant No. DE-FC02-06ER64159), and the National Science Foundation Graduate Research Fellowship (under Grant No. DGE-0738622).

Edited by: P. Stoy

\section{References}

Abelson, P. H.: The Arctic - a key to world climate, Science, 243, 873-873, 1989.

Baldocchi, D. D., Hicks, B. B., and Meyers, T. P.: Measuring biosphere-atmosphere exchanges of biologically related gases with micrometeorological methods, Ecology, 69, 1331-1340, 1988.

Bellisario, L. M., Bubier, J. L., Moore, T. R., and Chanton, J. P.: Controls on $\mathrm{CH}_{4}$ emissions from a northern peatland, Global Biogeochem. Cy., 13, 81-91, doi:10.1029/1998gb900021, 1999.

Billings, W. D. and Peterson, K. M.: Vegetational change and icewedge polygons through the thaw-lake cycle in Arctic Alaska, Arctic Alpine Res., 12, 413-432, 1980.

Black, R. F.: Gubik formation of Quaternary age in northern Alaska, U.S. Geological Survey Professional Paper 302-C, 59-91, 1964.

Bockheim, J. G., Everett, L. R., Hinkel, K. M., Nelson, F. E., and Brown, J.: Soil organic carbon storage and distribution in arctic tundra, Barrow, Alaska, Soil Sci. Soc. Am. J., 63, 934-940, 1999.

Brewer, M. C.: Some results of geothermal investigatinos of permafrost in northern Alaska, Eos Transactions, American Geophysical Union, 39, 19-26, 1958.

Brown, L. C. and Duguay, C. R.: The fate of lake ice in the North American Arctic, The Cryosphere, 5, 869-892, doi:10.5194/tc5-869-2011, 2011.

Bubier, J., Costello, A., Moore, T. R., Roulet, N. T., and Savage, K.: Microtopography and methane flux in boreal peatlands, northern Ontario, Canada, Can. J. Bot., 71, 1056-1063, 1993.

Bubier, J. L., Moore, T. R., Bellisario, L., Comer, N. T., and Crill, P. M.: Ecological controls on methane emissions from a northern peatland complex in the zone of discontinuous permafrost, Manitoba, Canada, Global Biogeochem. Cy., 9, 455470, doi:10.1029/95gb02379, 1995.

Cabot, E. C.: The northern Alaskan coastal plain interpreted from aerial photographs, Geogr. Rev., 37, 639-648, 1947.

Callaghan, T. V., Bergholm, F., Christensen, T. R., Jonasson, C., Kokfelt, U., and Johansson, M.: A new climate era in the subArctic: Accelerating climate changes and multiple impacts, Geophys. Res. Lett., 37, L14705, doi:10.1029/2009g1042064, 2010.

Carson, C. E.: Radiocarbon dating of lacustrine strands in Arctic Alaska, Arctic, 21, 12-26, 1968.

Christensen, T. R.: Methane emission from Arctic tundra, Biogeochemistry, 21, 117-139, 1993.

Christensen, T. R., Ekberg, A., Strom, L., Mastepanov, M., Panikov, N., Oquist, M., Svensson, B. H., Nykanen, H., Martikainen, P. J., and Oskarsson, H.: Factors controlling large scale variations in methane emissions from wetlands, Geophys. Res. Lett., 30, 1414, doi:10.1029/2002GL016848, 2003.

Corradi, C., Kolle, O., Walter, K., Zimov, S. A., and Schulze, E. D.: Carbon dioxide and methane exchange of a north-east Siberian tussock tundra, Glob. Change Biol., 11, 1910-1925, doi:10.1111/j.1365-2486.2005.01023.x, 2005.

Denman, K. L., Brasseur, G., Chidthaisong, A., Ciais, P., Cox, P. M., Dickinson, R. E., Hauglustaine, D., Heinze, C., Holland, E., Jacob, D., Lohmann, U., Ramachandran, S., da Silva Dias, P. L., Wofsy, S. C., and Zhang, X.: Couplings Between Changes in the Climate System and Biogeochemistry, in: Climate Change 2007: The Physical Science Basis. Contribution of Working Group I to the Fourth Assessment Report of the Intergovernmental Panel on Climate Change, edited by: Solomon, S., Qin, D., Manning, 
M., Chen, Z., Marquis, M., Averyt, K. B., Tignor, M., and Miller, H. L., Cambridge University Press, Cambridge, United Kingdom and New York, NY, USA, 2007.

Desyatkin, A. R., Takakai, F., Fedorov, P. P., Nikolaeva, M. C., Desyatkin, R. V., and Hatano, R.: $\mathrm{CH}_{4}$ emission from different stages of thermokarst formation in Central Yakutia, East Siberia, Soil Sci. Plant Nutr., 55, 558-570, doi:10.1111/j.17470765.2009.00389.x, 2009.

Drew, J. V., Tedrow, J. C. F., Shanks, R. E., and Koranda, J. J.: Rate and depth of thaw in arctic soils, Transactions of the American Geophysical Union, 39, 697-701, 1958.

Euskirchen, E. S., McGuire, A. D., Kicklighter, D. W., Zhuang, Q., Clein, J. S., Dargaville, R. J., Dye, D. G., Kimball, J. S., McDonald, K. C., Melillo, J. M., Romanovsky, V. E., and Smith, N. V.: Importance of recent shifts in soil thermal dynamics on growing season length, productivity, and carbon sequestration in terrestrial high-latitude ecosystems, Glob. Change Biol., 12, 731-750, doi:10.1111/j.1365-2486.2006.01113.x, 2006.

Fan, S. M., Wofsy, S. C., Bakwin, P. S., Jacob, D. J., Anderson, S. M., Kebabian, P. L., McManus, J. B., Kolb, C. E., and Fitzjarrald, D. R.: Micrometeorological measurements of $\mathrm{CH}_{4}$ and $\mathrm{CO}_{2}$ exchange between the atmosphere and sub-arctic tundra, J. Geophys. Res.-Atmos., 97, 16627-16643, 1992.

Foken, T., Gockede, M., Mauder, M., Mahrt, L., Amiro, B., and Munger, W.: Post-field data quality control, in: Handbook of micrometeorology: a guide for surface flux measurement and analysis, edited by: Lee, X., Massman, W. J., and Law, B. E., Kluwer Academic Publishers, Dordrecht, 2004.

Forbrich, I., Kutzbach, L., Wille, C., Becker, T., Wu, J. B., and Wilmking, M.: Cross-evaluation of measurements of peatland methane emissions on microform and ecosystem scales using high-resolution landcover classification and source weight modelling, Agr. Forest Meteorol., 151, 864-874, doi:10.1016/j.agrformet.2011.02.006, 2011.

Forster, P., Ramaswamy, V., Artaxo, P., Berntsen, T., Betts, R., Fahey, D. W., Haywood, J., Lean, J., Lowe, D. C., Myhre, G., Nganga, J., Prinn, R., Raga, G., M., S., and Van Dorland, R.: Changes in Atmospheric Constituents and in Radiative Forcing, in: Climate Change 2007: The Physical Science Basis. Contribution of Working Group I to the Fourth Assessment Report of the Intergovernmental Panel on Climate Change, edited by: Solomon, S., Manning, M., Chen, Z., Marquis, M., Averyt, K. B., Tignor, M., and Miller, H. L., Cambridge University Press, Cambridge, United Kingdom and New York, NY, USA, 2007.

Friborg, T., Christensen, T. R., Hansen, B. U., Nordstroem, C., and Soegaard, H.: Trace gas exchange in a high-arctic valley 2. Landscape $\mathrm{CH}_{4}$ fluxes measured and modeled using eddy correlation data, Global Biogeochem. Cy., 14, 715-723, 2000.

Frohn, R. C., Hinkel, K. M., and Eisner, W. R.: Satellite remote sensing classification of thaw lakes and drained thaw lake basins on the North Slope of Alaska, Remote Sens. Environ., 97, 116126, doi:10.1016/j.rse.2005.04.022, 2005.

Goodrich, J. P. G. J. P., Varner, R. K., Frolking, S., Duncan, B. N., and Crill, P. M.: High-frequency measurements of methane ebullition over a growing season at a temperate peatland site, Geophys. Res. Lett., 38, L07404, doi:10.1029/2011g1046915, 2011.

Goswami, S., Gamon, J. A., and Tweedie, C. E.: Surface hydrology of an arctic ecosystem: Multiscale analysis of a flooding and draining experiment using spectral reflectance, J. Geophys. Res.-
Biogeo., 116, G00i07, doi:10.1029/2010jg001346, 2011.

Guo, D., Yang, M., and Wang, H.: Characteristics of land surface heat and water exchange under different soil freeze/thaw conditions over the central Tibetan Plateau, Hydrol. Process., 25, 2531-2541, doi:10.1002/hyp.8025, 2011.

Heyer, J., Berger, U., Kuzin, I. L., and Yakovlev, O. N.: Methane emissions from different ecosystem structures of the subarctic tundra in Western Siberia during midsummer and during the thawing period, Tellus B., 54, 231-249, doi:10.1034/j.16000889.2002.01280.x, 2002.

Hinkel, K. M., Eisner, W. R., Bockheim, J. G., Nelson, F. E., Peterson, K. M., and Dai, X. Y.: Spatial extent, age, and carbon stocks in drained thaw lake basins on the Barrow Peninsula, Alaska, Arct. Antarct. Alp. Res., 35, 291-300, 2003.

Hinzman, L. D., Kane, D. L., Gieck, R. E., and Everett, K. R.: Hydrologic and thermal-properties of the active layer in the Alaskan Arctic, Cold. Reg. Sci. Technol., 19, 95-110, 1991.

Hinzman, L. D., Bettex, N. D., Bolton, W. R., Chapin III, F. S., Dyurgerov, M. B., Fastie, C. L., Griffeth, B., Hollister, R. D., Hope, A., Huntington, H. P., Jensen, A. M., Jia, G., J,, Jorgenson, T., Kane, D. L., Klein, D. R., Kofinas, G., Lynch, A. H., Oechel, W., Osterkamp, T. E., Racine, C. H., Romanovsky, V. E., Stone, R. S., Stow, D., Sturm, M., Tweedie, C. E., Vourlitis, G. L., Walker, M. D., Walker, D., Webber, P. J., Welker, J., Winker, K. S., and Yoshikawa, K.: Evidence and Implications of Recent Climate Change in Northern Alaska and Other Arctic Regions, Climatic Change, 72, 251-298, 2005.

Hsieh, C. I., Katul, G., and Chi, T.: An approximate analytical model for footprint estimation of scaler fluxes in thermally stratified atmospheric flows, Adv. Water. Resour., 23, 765-772, 2000.

Hussey, K. M. and Michelson, R. W.: Tundra relief features near Point Barrow Alaska, Arctic, 19, 162-184, 1966.

Jackowicz-Korczynski, M., Christensen, T. R., Backstrand, K., Crill, P., Friborg, T., Mastepanov, M., and Strom, L.: Annual cycle of methane emission from a subarctic peatland, J. Geophys. Res.-Biogeo., 115, G02009, doi:10.1029/2008jg000913, 2010.

Jauhiainen, J., Takahashi, H., Heikkinen, J. E. P., Martikainen, P. J., and Vasander, H.: Carbon fluxes from a tropical peat swamp forest floor, Glob. Change Biol., 11, 1788-1797, doi:10.1111/j.1365-2486.2005.001031.x, 2005.

Joabsson, A. and Christensen, T. R.: Methane emissions from wetlands and their relationship with vascular plants: an Arctic example, Glob. Change Biol., 7, 919-932, 2001.

Jorgenson, M. T. and Shur, Y.: Evolution of lakes and basins in northern Alaska and discussion of the thaw lake cycle, J. Geophys. Res.-Earth., 112, F02s17, doi:10.1029/2006jf000531, 2007.

Jorgenson, M. T., Racine, C. H., Walters, J. C., and Osterkamp, T. E.: Permafrost degradation and ecological changes associated with a warming climate in central Alaska, Climatic Change, 48, 551-579, doi:10.1023/a:1005667424292, 2001.

Jorgenson, M. T., Shur, Y. L., and Pullman, E. R.: Abrupt increase in permafrost degradation in Arctic Alaska, Geophys. Res. Lett., 33, L02503, doi:10.1029/2005gl024960, 2006.

Kaimal, J. C., Wyngaard, J. C., Izumi, Y., and Cote, R.: Spectral characteristics of surface-layer turbulence, Q. J. Roy. Meteor. Soc., 98, 563-589, 1972.

Kelker, D. and Chanton, J.: The effect of clipping on methane emissions from Carex, Biogeochemistry, 39, 37-44, 
doi:10.1023/a:1005866403120, 1997.

Kim, Y. and Tanaka, N.: Effect of forest fire on the fluxes of $\mathrm{CO}_{2}$, $\mathrm{CH}_{4}$ and $\mathrm{N}_{2} \mathrm{O}$ in boreal forest soils, interior Alaska, J. Geophys. Res.-Atmos., 108, 8154, doi:10.1029/2001jd000663, 2003.

Kim, Y., Ueyama, M., Nakagawa, F., Tsunogai, U., Harazono, Y., and Tanaka, N.: Assessment of winter fluxes of $\mathrm{CO}_{2}$ and $\mathrm{CH}_{4}$ in boreal forest soils of central Alaska estimated by the profile method and the chamber method: a diagnosis of methane emission and implications for the regional carbon budget, Tellus B., 59, 223-233, doi:10.1111/j.1600-0889.2006.00233.x, 2007.

Kutzbach, L., Wagner, D., and Pfeiffer, E. M.: Effect of microrelief and vegetation on methane emission from wet polygonal tundra, Lena Delta, Northern Siberia, Biogeochemistry, 69, 341-362, 2004.

Leffingwell, E. d. K.: The Canning River region, northern Alaska, U.S. Geological Survey Professional Paper, 109, 251 pp., 1919.

Lipson, D. A., Jha, M., Raab, T. K., and Oechel, W. C.: Reduction of iron (III) and humic substances plays a major role in anaerobic respiration in an Arctic peat soil, J. Geophys. Res.-Biogeo., 115, G00i06, doi:10.1029/2009jg001147, 2010.

Mastepanov, M., Sigsgaard, C., Dlugokencky, E. J., Houweling, S., Strom, L., Tamstorf, M. P., and Christensen, T. R.: Large tundra methane burst during onset of freezing, Nature, 456, 628-658, doi:10.1038/nature07464, 2008.

McDermitt, D., Burba, G., Xu, L., Anderson, T., Komissarov, A., Riensche, B., Schedlbauer, J., Starr, G., Zona, D., Oechel, W., Oberbauer, S., and Hastings, S.: A new low-power, openpath instrument for measuring methane flux by eddy covariance, Appl. Phys. B.-Lasers O., 102, 391-405, doi:10.1007/s00340010-4307-0, 2010.

Merbold, L., Kutsch, W. L., Corradi, C., Kolle, O., Rebmann, C., Stoy, P. C., Zimov, S. A., and Schulze, E. D.: Artificial drainage and associated carbon fluxes $\left(\mathrm{CO}_{2} / \mathrm{CH}_{4}\right)$ in a tundra ecosystem, Glob. Change Biol., 15, 2599-2614, doi:10.1111/j.13652486.2009.01962.x, 2009.

Moore, C. J.: Frequency-response corrections for eddy-correlation systems, Bound.-Lay. Meteorol., 37, 17-35, 1986.

Morrissey, L. A. and Livingston, G. P.: Methane emissions from Alaska Arctic tundra - an assessment of local spatial variability, J. Geophys. Res.-Atmos., 97, 16661-16670, 1992.

Muller, S. V., Racoviteanu, A. E., and Walker, D. A.: Landsat MSS-derived land-cover map of northern Alaska: extrapolation methods and a comparison with photo-interpreted and AVHRRderived maps, Int. J. Remote Sens., 20, 2921-2946, 1999.

Oechel, W. C., Hastings, S. J., Vourlitis, G., Jenkins, M., Riechers, G., and Grulke, N.: Recent change of Arctic tundra ecosystems from a net carbon-dioxide sink to a source, Nature, 361, 520523, 1993

Oechel, W. C., Vourlitis, G., and Hastings, S. J.: Cold season $\mathrm{CO}_{2}$ emission from arctic soils, Global Biogeochem. Cy., 11, 163172,1997

Olivas, P. C., Oberbauer, S. F., Tweedie, C. E., Oechel, W. C., and Kuchy, A.: Responses of $\mathrm{CO}_{2}$ flux components of Alaskan Coastal Plain tundra to shifts in water table, J. Geophys. Res.Biogeo., 115, G00i05, doi:10.1029/2009jg001254, 2010.

Panikov, N. S., Flanagan, P. W., Oechel, W. C., Mastepanov, M. A., and Christensen, T. R.: Microbial activity in soils frozen to below -39 degrees C, Soil. Biol. Biochem., 38, 785-794, doi:10.1016/j.soilbio.2005.07.004, 2006.
Parmentier, F. J. W., van Huissteden, J., van der Molen, M. K., Schaepman-Strub, G., Karsanaev, S. A., Maximov, T. C., and Dolman, A. J.: Spatial and temporal dynamics in eddy covariance observations of methane fluxes at a tundra site in northeastern Siberia, J. Geophys. Res.-Biogeo., 116, G03016, doi:10.1029/2010jg001637, 2011.

Plug, L. J., Walls, C., and Scott, B. M.: Tundra lake changes from 1978 to 2001 on the Tuktoyaktuk Peninsula, western Canadian Arctic, Geophys. Res. Lett., 35, L03502, doi:10.1029/2007g1032303, 2008.

Raynolds, M. K., Walker, D. A., and Maier, H. A.: Plant community-level mapping of arctic Alaska based on the Circumpolar Arctic Vegetation Map, Phytocoenologia, 35, 821-848, doi:10.1127/0340-269x/2005/0035-0821, 2005.

Rhew, R. C., Teh, Y. A., and Abel, T.: Methyl halide and methane fluxes in the northern Alaskan coastal tundra, J. Geophys. Res.Biogeo., 112, G02009, doi:10.1029/2006jg000314, 2007.

Riordan, B., Verbyla, D., and McGuire, A. D.: Shrinking ponds in subarctic Alaska based on 1950-2002 remotely sensed images, J. Geophys. Res.-Biogeo., 111, G04002, doi:10.1029/2005jg000150, 2006.

Rodhe, H.: A comparison of the contribution of various gases to the greenhouse-effect, Science, 248, 1217-1219, 1990.

Romanovsky, V. E. and Osterkamp, T. E.: Effects of unfrozen water on heat and mass transport processes in the active layer and permafrost, Permafrost Periglac., 11, 219-239, doi:10.1002/10991530(200007/09)11:3<219::aid-ppp352>3.0.co;2-7, 2000.

Roulet, N., Moore, T., Bubier, J., and Lafleur, P.: Northern fens methane flux and climatic-change, Tellus B, 44, 100-105, 1992.

Sachs, T., Wille, C., Boike, J., and Kutzbach, L.: Environmental controls on ecosystem-scale $\mathrm{CH}_{4}$ emission from polygonal tundra in the Lena River Delta, Siberia, J. Geophys. Res.-Biogeo., 113, G00a03, doi:10.1029/2007jg000505, 2008.

Sachs, T., Giebels, M., Boike, J., and Kutzbach, L.: Environmental controls on $\mathrm{CH}_{4}$ emission from polygonal tundra on the microsite scale in the Lena river delta, Siberia, Glob. Change Biol. 16, 3096-3110, doi:10.1111/j.1365-2486.2010.02232.x, 2010.

Schimel, J. P.: Plant-transport and methane production as controls on methane flux from arctic wet meadow tundra, Biogeochemistry, 28, 183-200, doi:10.1007/bf02186458, 1995.

Schuur, E. A. G., Bockheim, J., Canadell, J. G., Euskirchen, E., Field, C. B., Goryachkin, S. V., Hagemann, S., Kuhry, P., Lafleur, P. M., Lee, H., Mazhitova, G., Nelson, F. E., Rinke, A., Romanovsky, V. E., Shiklomanov, N., Tarnocai, C., Venevsky, S., Vogel, J. G., and Zimov, S. A.: Vulnerability of permafrost carbon to climate change: Implications for the global carbon cycle, Bioscience, 58, 701-714, doi:10.1641/b580807, 2008.

Schuur, E. A. G., Vogel, J. G., Crummer, K. G., Lee, H., Sickman, J. O., and Osterkamp, T. E.: The effect of permafrost thaw on old carbon release and net carbon exchange from tundra, Nature, 459, 556-559, doi:10.1038/nature08031, 2009.

Sebacher, D. I., Harriss, R. C., Bartlett, K. B., Sebacher, S. M., and Grice, S. S.: Atmospheric methane sources: Alaskan tundra bogs, an alpine fen, and a subarctic boreal marsh, Tellus B, 38B, 1-10, doi:10.1111/j.1600-0889.1986.tb00083.x, 1986.

Serreze, M. C., Walsh, J. E., Chapin, F. S., Osterkamp, T., Dyurgerov, M., Romanovsky, V., Oechel, W. C., Morison, J., Zhang, T., and Barry, R. G.: Observational evidence of recent change in the northern high-latitude environment, Climatic Change, 46, 
$159-207,2000$

Shiklomanov, N. I., Streletskiy, D. A., Nelson, F. E., Hollister, R. D., Romanovsky, V. E., Tweedie, C. E., Bockheim, J. G., and Brown, J.: Decadal variations of active-layer thickness in moisture-controlled landscapes, Barrow, Alaska, J. Geophys. Res.-Biogeo., 115, G00i04, doi:10.1029/2009jg001248, 2010.

Smith, L. C., Sheng, Y., MacDonald, G. M., and Hinzman, L. D.: Disappearing Arctic lakes, Science, 308, 1429-1429, doi:10.1126/science.1108142, 2005.

Strack, M. and Waddington, J. M.: Response of peatland carbon dioxide and methane fluxes to a water table drawdown experiment, Global Biogeochem. Cy., 21, Gb1007, doi:10.1029/2006gb002715, 2007.

Tanaka, K., Tamagawa, I., Ishikawa, H., Ma, Y. M., and Hu, Z. Y.: Surface energy budget and closure of the eastern Tibetan Plateau during the GAME-Tibet IOP 1998, J. Hydrol., 283, 169-183, doi:10.1016/s0022-1694(03)00243-9, 2003.

Tarnocai, C., Canadell, J. G., Schuur, E. A. G., Kuhry, P., Mazhitova, G., and Zimov, S.: Soil organic carbon pools in the northern circumpolar permafrost region, Global Biogeochem. Cy., 23, Gb2023, doi:10.1029/2008gb003327, 2009.

Trenberth, K. E., Jones, P. D., Ambenje, P., Bojariu, R., Easterling, D., Klein Tank, A., Parker, D., Rahimzadeh, F., Renwick, J. A., Rusticucci, M., B., S., and Zhai, P.: Observations: Surface and Atmospheric Climate Change, in: Climate Change 2007: The Physical Science Basis. Climate Change 2007: The Physical Science Basis, edited by: Solomon, S., Qin, D., Manning, M., Chen, Z., Marquis, M., Averyt, K. B., Tignor, M., and Miller, H. L., Cambridge University Press, Cambridge, United Kingdom and New York, NY, USA, 2007.

von Fischer, J. C., Rhew, R. C., Ames, G. M., Fosdick, B. K., and von Fischer, P. E.: Vegetation height and other controls of spatial variability in methane emissions from the Arctic coastal tundra at Barrow, Alaska, J. Geophys. Res., 115, G00I03, doi:10.1029/2009jg001283, 2010.

Vourlitis, G., Oechel, W., Hastings, S. J., and Jenkins, M.: The effect of soil moisture and thaw depth on $\mathrm{CH}_{4}$ flux from wet sedge tundra ecosystems on the North Slope of Alaska, Chemosphere, 26, 329-337, 1993.

Vourlitis, G. L., Oechel, W. C., Hastings, S. J., and Jenkins, M. A.: The effect of soil-moisture and thaw depth on $\mathrm{CH}_{4}$ flux from wet coastal tundra ecosystems on the North Slope of Alaska (vol. 26, p. 329, 1993), Chemosphere, 28, R1-R3, 1994.

Wagner, D., Gattinger, A., Embacher, A., Pfeiffer, E. M., Schloter, M., and Lipski, A.: Methanogenic activity and biomass in Holocene permafrost deposits of the Lena Delta, Siberian Arctic and its implication for the global methane budge, Glob. Change Biol., 13, 1089-1099, doi:10.1111/j.1365-2486.2007.01331.x, 2007.
Walter, B. P. and Heimann, M.: A process-based, climate-sensitive model to derive methane emissions from natural wetlands: Application to five wetland sites, sensitivity to model parameters, and climate, Global Biogeochem. Cy., 14, 745-765, 2000.

Walter, K. M., Zimov, S. A., Chanton, J. P., Verbyla, D., and Chapin, F. S.: Methane bubbling from Siberian thaw lakes as a positive feedback to climate warming, Nature, 443, 71-75, doi:10.1038/nature05040, 2006.

Walter, K. M., Smith, L. C., and Chapin, F. S.: Methane bubbling from northern lakes: present and future contributions to the global methane budget, Phil. T. R. Soc. A, 365, 1657-1676, doi:10.1098/rsta.2007.2036, 2007

Webb, E. K., Pearman, G. I., and Leuning, R.: Correction of flux measurements for density effects due to heat and water-vapor transfer, Q. J. Roy. Meteor. Soc., 106, 85-100, 1980.

Whalen, S. C. and Reeburgh, W. S.: A methane flux time series for tundra environments, Global Biogeochem. Cy., 2, 399-409, doi:10.1029/GB002i004p00399, 1988.

Whalen, S. C. and Reeburgh, W. S.: Consumption of atmospheric methane by tundra soils, Nature, 346, 160-162, 1990.

Whalen, S. C. and Reeburgh, W. S.: Interannual variations in tundra methane emission: A 4-year time series at fixed sites, Global Biogeochem. Cy., 6, 139-159, doi:10.1029/92gb00430, 1992.

Wille, C., Kutzbach, L., Sachs, T., Wagner, D., and Pfeiffer, E. M.: Methane emission from Siberian arctic polygonal tundra: eddy covariance measurements and modeling, Glob. Change Biol., 14, 1395-1408, doi:10.1111/j.1365-2486.2008.01586.x, 2008.

Wilson, K., Goldstein, A., Falge, E., Aubinet, M., Baldocchi, D., Berbigier, P., Bernhofer, C., Ceulemans, R., Dolman, H., Field, C., Grelle, A., Ibrom, A., Law, B. E., Kowalski, A., Meyers, T., Moncrieff, J., Monson, R., Oechel, W., Tenhunen, J., Valentini, R., and Verma, S.: Energy balance closure at FLUXNET sites, Agr. Forest Meteorol., 113, 223-243, 2002.

Zhuang, Q., Melillo, J. M., Kicklighter, D. W., Prinn, R. G., McGuire, A. D., Steudler, P. A., Felzer, B. S., and Hu, S.: Methane fluxes between terrestrial ecosystems and the atmosphere at northern high latitudes during the past century: A retrospective analysis with a process-based biogeochemistry model, Global Biogeochem. Cy., 18, Gb3010, doi:10.1029/2004gb002239, 2004.

Zona, D., Oechel, W. C., Kochendorfer, J., U, K. T. P., Salyuk, A. N., Olivas, P. C., Oberbauer, S. F., and Lipson, D. A.: Methane fluxes during the initiation of a large-scale water table manipulation experiment in the Alaskan Arctic tundra, Global Biogeochem. Cy., 23, Gb2013, doi:10.1029/2009gb003487, 2009.

Zona, D., Lipson, D. A., Zulueta, R. C., Oberbauer, S. F., and Oechel, W. C.: Microtopographic controls on ecosystem functioning in the Arctic Coastal Plain, J. Geophys. Res.-Biogeo., 116, G00I08, doi:10.1029/2009jg001241, 2011. 